\title{
THE LATE OLIGOCENE RODENT FAUNAS OF CANALES (MP28) AND PARRALES (MP29) FROM THE LORANCA BASIN, PROVINCE OF CUENCA, SPAIN
}

\author{
$M^{a}$ de los Ángeles ÁLVAREZ SIERRA', Remmert DAAMS \\ and Pablo PELÁEZ- CAMPOMANES ${ }^{1,2}$
}

\begin{abstract}
' Departamento y UEI de Paleontología, Facultad de Ciencias Geológicas, Universidad Complutense, Ciudad Universitaria, 28040 Madrid, Spain. E-mail: masierra@eucmax.sim.ucm.es, daams@euc.max.sim.ucm.es,ppcl@eucmax.sim.ucm.es

${ }^{2}$ Museo de Ciencias Naturales, Departamento de Paleodiversidad, c/ Gutiérrez Abascal 2, 28006 Madrid, Spain.
\end{abstract}

\begin{abstract}
Álvarez Sierra, M.A., Daams, R. and Peláez-Campomanes, P. 1999. The Late Oligocene rodent faunas of Canales (MP28) and Parrales (MP 29) from the Loranca Basin, province of Cuenca, Spain. [Las faunas de roedores de Canales (MP28) y Parrales (MP29) del Oligoceno Superior de la Cuenca de Loranca, provincia de Cuenca, España]. Revista Española de Paleontología, 14 (1), 93-116. ISSN 0213-6937.
\end{abstract}

\begin{abstract}
Two rodent faunas from the Upper Oligocene fluvial sediments of the Upper Detrital Unit of the Loranca Basin are described. The oldest fauna of Canales contains Issiodoromys limognensis and is correlated to MP28; the other, more modern fauna of Parrales contains I. pseudanaema and it is correlated to MP29. The cricetid genera Adelomyarion Hugueney, 1969 and Allocricetodon Freudenthal, 1994 are reviewed and the latter one is considered to be a junior synonym of the former one. The faunas are compared to other Spanish late Oligocene faunas such as Vivel de Río, Hinojosa de Jarque, and Sayatón 1 and 6. The resulting succession is correlated to the most important remaining European late Oligocene localities, and the biochronological subdivision of this period is discussed.
\end{abstract}

Keywords: Rodents, biochronology, Upper Oligocene, Loranca Basin, Spain.

\section{RESUMEN}

Se describen dos asociaciones de roedores fósiles procedentes de depósitos fluviales del Oligoceno Superior localizados en la Unidad Detrítica Superior de la Cuenca de Loranca. El yacimiento de Canales es el más antiguo, contiene Issiodoromys limognensis y pertenece a la MP28; el otro yacimiento, Parrales, contiene $I$. pseudanaema y pertenece a la MP29. Se realiza la revisión de los cricétidos Adelomyarion Hugueney, 1969 y Allocricetodon Freudenthal, 1994, y se propone la sinonimia de estos dos géneros. Estas faunas se comparan con otras faunas españolas del Oligoceno Superior, como Vivel del Río, Hinojosa de Jarque y Sayatón 1 y 6. La sucesión resultante se correlaciona con las localidades más importantes del Oligoceno Superior europeo, y se discute la subdivisión biocronológica para el Oligoceno Superior.

Palabras clave: Roedores, biocronología, Oligoceno Superior, Cuenca de Loranca, España.

\section{INTRODUCTION}

The Loranca Basin is situated in the central eastern part of Spain (Fig. 1) and it is considered to be the vastest internal depression of the Iberian Range. The western margin of the basin is defined by the thrust belt of the Sierra de Altomira and the eastern limit is formed by the folded Serranía de Cuenca.

Three major stratigraphic units are recognized in the
Tertiary stratigraphic succession of this basin; the Lower Detrital Unit, the Upper Detrital Unit, and the Terminal Unit respectively (Díaz Molina \& López Martínez, 1979). The deposition of the Lower Detrital Unit was synchronous with the deformational event that formed the Sierra de Altomira and the Loranca Basin during Eocene to Late Oligocene times. The Upper Detrital Unit of the Loranca Basin is about $900 \mathrm{~m}$ thick and it filled the basin from the Late Oligocene to the Early Miocene. The 


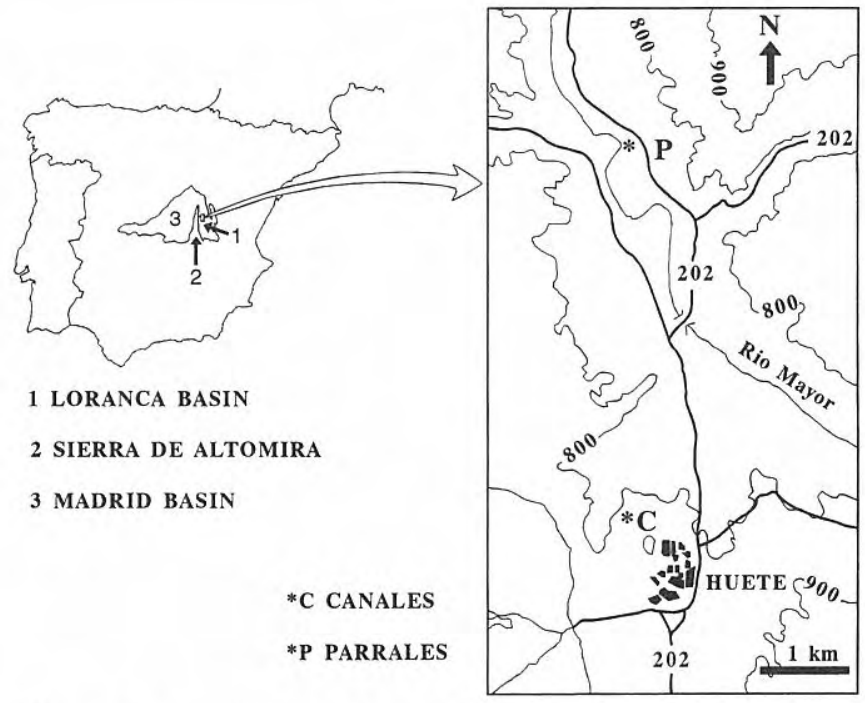

Figure 1. Geographic situation of the two studied Upper Oligocene localities.

Terminal Unit is of Early - Middle Miocene age.

The Canales level is situated near the village of Huete (Fig. 1) and consists of a light-grey silt with scattered small gastropod fragments and tiny gypsum crystals in a sequence of predominantly fluvial deposits of the Upper Detrital Unit. Some $6200 \mathrm{~kg}$ of sediment were screened, which yielded approximately 96 dental remains of rodents. These sediments are exposed in the eastern and western flanks of the N-S striking anticline of Huete. The level of Parrales is exposed at the eastern border of the Río Mayor some $2 \mathrm{~km}$ north of Huete and consists of a fine yellow-grey silt with small conglomeratic elements of calcareous algae at the bottom of a channel. $3725 \mathrm{~kg}$ were sampled which yielded 149 rodent teeth.

The teeth were measured using a Nikon monocular digital measuring microscope: measurements are given in $0.1 \mathrm{~mm}$ units. The nomenclature of the cheek teeth is for the Theridomyidae after Vianey-Liaud (1972), for the Gliridae after Daams (1981), for the Eomyidae after Álvarez Sierra (1987), and for the Cricetidae after Freudenthal et al. (1994). The specimens are stored at the Department of Paleontology of the Complutense University of Madrid.

\section{SYSTEMATIC DESCRIPTION}

\section{CANALES}

Family Theridomyidae Alston, 1876

\section{Issiodoromys limognensis Schmidt-Kittler \& Vianey-Liaud, 1987$$
\text { Pl. I, figs. 1-3 }
$$

Material and Measurements: Because of the bad state of preservation only three $M_{1.2}$ could be measured. The length, width and height of these three teeth are respectively $21.6 \mathrm{x}$ 15.2 x —; 274 x 16.0 × 52.0; 20.0 x - x 41.2. Remaining material consists of fragments of $3 \mathrm{D}^{4}, 1 \mathrm{P}^{4}, 9 \mathrm{M}^{1.2}, 1 \mathrm{M}^{3}, 2 \mathrm{D}_{4}$, $1 \mathrm{P}_{4}, 4 \mathrm{M}_{1,2}, 2 \mathrm{M}_{3}$.

\section{Discussion}

Because of the scarcity and the bad preservation of the material, a good description has not been possible, although the sinus(id) contains cement. The measurements of the occlusal surface (length and width) are similar to those of $I$. quercyi_(Schlosser) and $I$. limognensis. The estimated hypsodonty of our material is similar to the mean value of the hypsodonty of $I$. limognensis from Pech Fraysse and Vivel del Río (Hugueney et al., 1987), measured in $\mathrm{M}_{1-2}$ with the sinclinid III with island shape, and larger than the mean value of Pech Desse (Hugueney et al, 1987).

Family Cricetidae Rochebrune, 1883

Adelomyarion Hugueney, 1969

*1969 Adelomyarion Hugueney, 56.

1994 Allocricetodon Freudenthal, 12-15.

\section{Adelomyarion cornelii (Freudenthal, 1994)}

$$
\text { Pl. II, figs. 4, } 5
$$

Material and measurements: 1 fragmentary $\mathrm{M}^{1}(-\mathrm{x} 12.1$ approximately); $1 \mathrm{M}^{2}(13.6 \times 12.9) ; 1 \mathrm{M}^{3}(10.5 \mathrm{x}-) ; 1 \mathrm{M}_{2}$ (13.7 x 11.6); $1 \mathrm{M}_{3}$.

\section{Description}

$M^{\prime}$ : The anterior part of the tooth is missing. The anterior arm of the hypocone joins the posterior wall of the protocone below the occlusal surface. Two short mesolophs extend into the mesosinus. The metalophule points obliquely forward and joins the anterior part of the hypocone. The posteroloph encloses the posterosinus.

$\mathrm{M}^{2}$ : The labial anteroloph encloses the anterosinus and meets the basis of the paracone. The well-developed, lingual anteroloph descends along the lingual tooth border and ends in a cusp at the posterior basis of the protocone, thus separating the protocone from the tooth border. A long, and well-developed posterior spur of the paracone descends toward the labial tooth border where it ends just before reaching the independent mesostyl. The anterior arm of the hypocone points obliquely forward into the mesosinus, where it bifurcates. One end continues as a short mesoloph into the mesosinus, and the other end joins the labial wall of the protocone. The metalophule is more or less transverse, and joins the anterior part of the hypocone. From the top of the metacone a spur descends into the mesosinus toward the end of the paracone spur, but without reaching it. The welldeveloped posteroloph is connected to the metacone, thus closing the posterosinus.

$\mathrm{M}^{3}$ : The labial anteroloph joins the basis of the paracone, thus enclosing the labial anterosinus. The lingual anteroloph descends to the basis of the protocone. The protolophule points obliquely forward and joins the junction of the labial and lingual anteroloph. The endoloph descends from the 
protocone and meets the anterior wall of the hypocone well below the occlusal surface. The anterior arm of the hypocone points obliquely forward and ends free in the mesosinus. The metacone has an anterior spur which descends into the mesosinus. The posteroloph encloses the posterosinus.

$\mathrm{M}_{2}$ : The medium-long, lingual anterolophid is connected to the anterior basis of the metaconid, thus closing the anterosinusid. The labial anterolophid descends and continues along the labial basis of the protoconid to the anterior basis of the hypoconid, thus bordering the sinusid. The metalophulid points sharply forward and meets the anteroconid. The posterior arm of the protoconid extends halfway into the mesosinusid, where it bifurcates. One part ends as a short mesolophid and the other part joins the forward pointing hypoconid. The hypolophulid points backwards. The posterolophid ascends to about halfway the posterior wall of the entoconid, thus closing the posterosinusid.

$\mathrm{M}_{3}$ : The medium-long, lingual anterolophid is connected to the anterior basis of the metaconid, thus closing the anterosinusid. The labial anterolophid descends to the basis of the protoconid reaching it. The metalophulid points sharply forward and meets the anteroconid. A second metalophulid connects the metaconid to the posterior arm of the protoconid. The posterior arm of the protoconid points obliquely backward and curves round longitudinally to meet the transverse hypolophulid. The posterolophid is connected to the top of the entoconid, thus enclosing the posterosinusid.

\section{Discussion}

Freudenthal (1994) defined Allocricetodon with his new species Allocricetodon cornelii from Mirambueno 1 (unit MP28) as the type species. Heterocricetodon landroveri Daams et al., 1989 (MP25) and Pseudocricetodon incertus (Schlosser, 1884) (MP25-27) were also included in the genus. It appeared however that the diagnostic features to distinguish Allocricetodon from Adelomyarion are not obvious (Table 1). Both are of medium size, and the only difference in the lower molars, is the length of the posterior arm of the protoconid. However, the personal appreciation of this feature may influence in the characterization and does therefore not serve for generic distinction. If the longitudinal ridge is continuous and no mesolophid-like ridge extends as a continuation of the posterior arm into the mesosinusid, we consider the posterior arm of the protoconid to be absent. In more modern representatives of Adelomyarion the longitudinal ridge tends to be interrupted and the protoconid exhibits an oblique posterior arm ending free in the mesosinusid. So, the absence of a longitudinal ridge makes it seem that there is a well-developed posterior arm of the protoconid. The generic diagnosis of Allocricetodon is based on species from MP25-28 levels, and since Adelomyarion is from more modern levels, this difference represents a different evolutionary stage. Another distinctive feature would be the anteroconeparacone connection of $\mathrm{M}^{1}$. In Allocricetodon it would be frequently present according to Freudenthal (1994), but our own observations showed that this feature is also present in Adelomyarion. Judging from table 15 (character 4, state 5) in Freudenthal (1994), it appears that this connection is present in $10 \%(\mathrm{~N}=10)$ of $A$. incertus from Mirambueno 4C (MP25-26) and in $39.5 \%$ ( $\mathrm{N}=38$ ) of $A$. cornelii from Mirambueno 1 (MP28). Adelomyarion vireti Hugueney, 1969 from La Milloque (MP29, Brunet, 1979) shows this feature in $19 \%(\mathrm{~N}>25)$ and A. alberti Daams, 1989 from Sayatón 6 also in $19 \%$ $(\mathrm{N}=21)$ (Daams, 1989). Another distinctive feature would be the outline of $\mathrm{M}^{2}$. In Allocricetodon it is trapezoidal according to Freudenthal (1994), but our own appreciation is that of subquadrate. Moreover, comparing figures of the various species of these two genera, no difference in outline whatsoever is observed. Summarizing, the only distinctive feature to distinguish Adelomyarion from Allocricetodon would be the interrupted longitudinal ridge of the lower molars. Furthermore, several characters present in the type species of Allocricetodon are even diagnostic for Adelomyarion. One of these features, not mentioned by Freudenthal, is the direction of the paracone-protolophule complex of $\mathrm{M}^{1}$. In $A$. incertus it tends to be proverse, and in $A$. cornelii, A. alberti and $A$. vireti this complex is strongly proverse. Another feature is the protoconeentoloph connection in $\mathrm{M}^{2}$. In $A$. incertus from Mirambueno $4 \mathrm{C}$ and in $A$. cornelii from Mirambueno 1 this connection is predominantly low (Freudenthal, 1994, table 16, character 9). This low connection or the absence of this connection is characteristic for the more modern $A$. vireti and $A$. alberti. The same feature is observed in $\mathrm{M}^{\prime}$, but less conspicuous. Consequently Allocricetodon is considered to be a junior synonym of Adelomyarion.

The material from Vivel del Río assigned to Allocricetodon cornelii by Freudenthal (1994), is too poor in order to make a statistical comparison. Surprisingly Freudenthal (1994) did not even mention or compare his material to Adelomyarion. The material from Vivel, collected by Adrover, and described by Hugueney et al. (1987) as Adelomyarion sp. agrees with Adelomyarion cornelii.

Hugueney et al. (1987) noted the resemblance between A. incertus and Adelomyarion sp. from Vivel and suggest that the former be the ancestor of the latter. We propose here an evolutionary lineage of Adelomyarion incertus - cornelii - vireti which is characterized by the following trends:

1. Simplification of the dental pattern by the loss of mesoloph(id)s

2. Relative size decrease of $\mathrm{M}_{3}$

3. Reduction of the anterocone complex in $\mathrm{M}^{1}$

4. Development of an obliquely forward pointing paracone-protolophule complex

5. Reduction of entoloph in upper molars and ectolophid in the lower ones. Interrupted longitudinal ridges are seen in $A$. vireti from the Upper Oligocene of Eggingen-Erdbeerhecke and Eggingen-Mittelhart 1 (Werner, 1994). A. alberti from Sayatón-6 is considered to be an endemic off-shoot of the main Adelomyarion lineage (Fig. 2). 
Heterocricetodon landroveri Daams et al., 1989 from MP25 of Pareja (Daams et al., 1989) and Mirambueno 4C+4D (Freudenthal, 1994) does not show the above mentioned dental features that are characteristic for Adelomyarion. As can be seen in Table 1 the features of Allocricetodon considered to be diagnostic by Freudenthal (1994) are also present in Heterocricetodon, with the exception of the size. We don't think that size is a reliable feature for generic separation and consequently Allocricetodon can't be distinguished from Heterocricetodon on the basis of the criteria given by Freudenthal (1994). This may explain why this author erroneously assigned Heterocricetodon landroveri to Allocricetodon.

Daams et al. (1989) mentioned that $A$. incertus from Carrascosa (MP25) may be attributed to H. landroveri in spite of some slight morphological differences. The large size difference (Fig. 3) does not allow such a statement however.

A. cornelii from Canales is of similar size and morphology as the type material of A. cornelii from Mirambueno 1 (Freudenthal, 1994). It is also of the same size as A. cornelii from Vivel del Río (Fig. 3). Table 3 in Freudenthal (1994) shows under $\mathrm{M}_{2}$ a very small specimen from Vivel del Río assigned to Adelomyarion cornelii, which however falls outside the range of variation of the type material and all other assemblages attributed to this species. Therefore we assign it to Adelomyarion sp. This small-sized species is present in Canales too (see below).

\section{Adelomyarion $\mathrm{sp}$. Pl. II, figs. 1-3}

Material and measurements: 1 fragmentary $\mathrm{M}^{1}, 1 \mathrm{M}^{2}(10.6$ x 10.9), $1 \mathrm{M}_{1}(14.3 \times 9.1)$ and $1 \mathrm{M}_{3}(10.9 \times 9.7)$.

\section{Description}

$\mathrm{M}^{\prime}$ : The enamel of the anterior and labial parts of the tooth are missing. The entoloph splits up into two arms towards the middle of the molar; the lingual arm joins the postero-lingual wall of the protocone, and the labial one is connected to the posterior wall of the paracone. The metalophule points obliquely forwards and it is connected to the anterior part of the hypocone.

$\mathrm{M}^{2}$ : The labial anteroloph nearly reaches the basis of the paracone, thus leaving the anterosinus open. The lingual anteroloph descends and continues along the lingual border to the basis of the hypocone, thus separating the protocone from the tooth border. The protolophule points obliquely forward and meets the anterior arm of the protocone. The sinus points sharply forward. The mesocone is visible as a slight inflation of the endoloph. A mesoloph is absent. The metalophule is more or less transverse and joins the endoloph before the hypocone. The posteroloph joins the metacone halfway, thus enclosing the posterosinus.

$\mathrm{M}_{1}$ : The small, sub-rounded anteroconid is lingually connected to the anterior spur of the metaconid, thus bordering the lingual anterosinusid. The labial spur of the anteroconid descends along the labial tooth border toward the basis of the protoconid without reaching it. The small metaconid meets the lingual extension of the protoconid. From the top of the metaconid a spur descends along the lingual border and reaches the basis of the entoconid, thus closing the mesosinusid. From the well-developed mesoconid a medium-long mesolophid extends into the mesosinusid, but without reaching the lingual border. The narrow entolophid connects the mesoconid to the posterior wall of the protoconid. The posterior part of the entolophid is wider and meets the anterior wall of the hypoconid. The hypolophulid is transverse and it joins the anterior part of the hypoconid. The posterolophid does not reach the basis of the entoconid, thus leaving the posterosinusid open. The sinusid is wide and transverse. A low and longitudinal ridge is present at the labial border of the sinusid.

$\mathrm{M}_{3}$ : The medium-long, lingual anterolophid is connected to the anterior basis of the metaconid, thus closing the anterosinusid. The labial anterolophid descends to the basis of the protoconid without reaching it. The metalophulid points sharply forward and meets the anteroconid. The posterior arm of the protoconid points obliquely backward and curves round longitudinally to meet the transverse hypolophulid. The posterolophid is connected to the top of the entoconid, thus enclosing the posterosinusid.

\section{Discussion}

The material from Canales has been assigned to the genus Adelomyarion mainly by the morphology of the entoloph of $\mathrm{M}^{\mathrm{i}}$ and its relatively small $\mathrm{M}_{3}$. Adelomyarion sp. from Canales is of smaller size and it has a less complicated dental pattern than A. alberti Daams, 1989 from the Upper Oligocene (MP30) of Sayatón 6. Its dental pattern agrees more with that of $A$. vireti but its teeth are of smaller size (Fig. 3). The material from Canales is smaller and less complex than Adelomyarion cornelii (Freudenthal, 1994) from Vivel del Rio (Adelomyarion sp. in Hugueney et al, 1987).

\section{Pseudocricetodon cf. adroveri Freudenthal, Hugueney \& Moissenet, 1994 Pl. III, figs. 1-3}

Material and measurements: 1 fragmentary $M^{1}(-x$

\section{Plate I}

1-3 Issiodoromys limognensis Schmidt-Kittler et VianeyLiaud, 1987 from Canales. 1. $M_{1.2}$ sin. (CAN 7), a-d: occlusal, lingual, labial and anterior views. 2. $M_{1,2} \sin$. (CAN 1). 3. $\mathrm{M}^{1.2}$ dext. (CAN 2), a-c, occlusal, lingual and anterior views.
4-5 Issiodoromys pseudanaema (Gervais, 1848) from Parrales. 4. $\mathrm{M}^{1.2}$ sin. (PAR 62), a-c, occlusal, posterior and lingual views. 5. $\mathrm{M}_{3}$ dext. (PAR 65).

The horizontal bar represents $1 \mathrm{~mm}$. 
Plate I
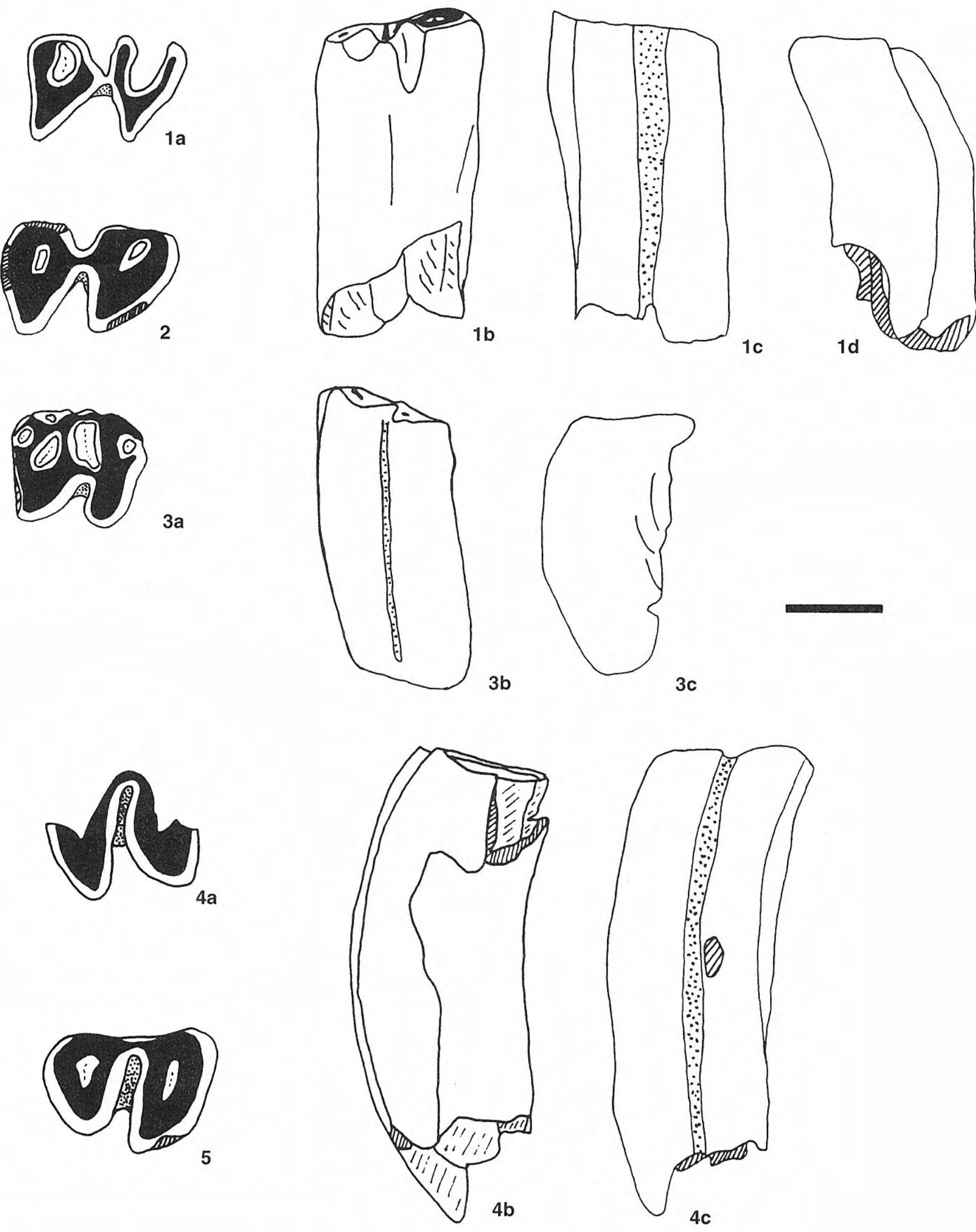

Revista Española de Paleontología, 14 (1), 1999. 
10.2); $4 \mathrm{M}^{2}(10.3 \times-, 10.6 \times 9.9,10.3 \times 9.8,-\mathrm{x} 9.7) ; 1 \mathrm{M}^{3}$ $(8.9 \times-) ; 1 \mathrm{M}_{1}(-\mathrm{x} 8.8) ; 2 \mathrm{M}_{2}(12.2 \times 10.4,12.3 \times 10.2) ; 1$ $\mathrm{M}_{3}(11.9 \times 9.8)$.

\section{Description}

$\mathrm{M}^{\mathrm{1}}$ : The anterior part of the anterocone is missing. The paracone is larger than the metacone. The anterior arm of the protocone is nearly transverse and ends free near the anterolingual border of the paracone. The short protolophule points slightly backward and joins the endoloph just behind the protocone. The sinus points sharply forward. The long, but interrupted, mesoloph reaches the labial border. The long metalophule is transverse and it joins the hypocone. The posteroloph is low and ends at the postero-labial basis of the metacone.

$M^{2}$ : The paracone is larger than the metacone. The protolophule is double. The labial anteroloph reaches the basis of the paracone. In one specimen a lingual anteroloph is present, which descends straight down to the crown basis. The complete, anterior protolophule points slightly forward and joins the anterior part of the protocone. The posterior protolophule sprouts from the endoloph behind the protocone and points obliquely forward toward the posterolingual basis of the paracone, without reaching this cusp, however. A medium-long mesoloph is present. One specimen has a mesostyl. The mesosinus is wide and flat. The metalophule is transverse in one specimen, and points obliquely forward in the other two. It joins the endoloph before the hypocone. The posteroloph descends from the hypocone to the labial border, without closing the posterosinus. The sinus points sharply forward.

$M_{1}$ : The anterior part of the tooth is missing. An ectomesolophid is present in the wide and transverse sinusid. A short and obliquely forward pointing mesolophid is present in the wide and shallow mesosinusid. The hypolophulid points slightly backward and joins the hypoconid. The posterolophid continues toward the top of the entoconid, thus enclosing the posterosinusid.

$\mathrm{M}_{2}$ : The metaconid is larger than the entoconid. The medium-long, lingual anterolophid encloses a hardly distinct anterosinusid. The labial anterolophid is very small. The metalophulid is transverse and meets the anterior part of the protoconid. The posterior arm of the protoconid points obliquely forward and sprouts from the entolophid. The entolophid is inflated behind the posterior metalophulid. The mesosinusid is wide and flat. Mesolophids are absent. A slightly elevated ridge sprouts from the entolophid into the transverse sinusid indicating the presence of an ectomesolophid. The hypolophulid is more or less transverse and joins the anterior part of the hypoconid. The posterolophid continues toward the top of the entoconid, thus enclosing the posterosinusid.

$\mathrm{M}_{3}$ : The medium-long, lingual anterolophid reaches the antero-labial basis of the metaconid. The labial anterolophid descends straight down to the anterior basis of the protoconid. The narrow and low anterior metalophulid joins the metaconid at the anterior extension of the protoconid. The transverse, posterior arm of the protoconid is short and ends free in the wide and plain mesosinusid. A short, obliquely forward pointing mesolophid is present. A slightly elevated ridge sprouts from the entolophid into the backward pointing sinusid indicating the presence of an ectomesolophid. A low and narrow, free-ending, more or less longitudinal, ridge extends from the entolophid into the posterosinusid.

\section{Discussion}

Hitherto six Pseudocricetodon species have been described. These species and their respective type localities are the following: P. montalbanensis Thaler from the Lower Oligocene (MP23) of Montalbán; $P$. philippi Hugueney from the Lower Oligocene (MP23) of St.-Martin-de-Castillon; P. moguntiacus (Bahlo, 1975) from the Lower Oligocene (MP24) of Heimersheim; $P$. simplex Freudenthal, Hugueney \& Moissenet, 1994 from the Upper Oligocene (MP25) of Mirambueno 4C; $P$. adroveri Freudenthal, Hugueney \& Moissenet, 1994 from the Upper Oligocene (MP28) of Vivel del Rio; and $P$. thaleri Hugueney, 1969 from the Upper Oligocene (MP30) of Coderet. P. philippi is far out the smallest species of the genus and it has a simple dental pattern (e.g. the mesolophid is always absent in $\mathrm{M}_{3}$ (Freudenthal et $a l, 1994)$ ). Therefore we consider our material from Canales not to belong to this species. The other five species have approximately similar size ranges and are of larger size than $P$. philippi.

$P$. moguntiacus is the largest species of the genus Pseudocricetodon (Dienemann, 1987). Our material fits in the size range of $P$. moguntiacus from Heimersheim (Bahlo, 1975) but morphologically they are different. $P$. moguntiacus differs from $P$. cf. adroveri from Canales by its better-developed paracone and metacone in $\mathrm{M}^{1}$ and $\mathrm{M}^{2}$, by its anterior arm of the protoconid pointing towards the anterocone, by its protolophule connection close to the anterocone in $\mathrm{M}^{2}$, by its ectolophid low and by its better-developed posterior arm of the protoconid, mesolophid and ectomesolophid in the $\mathrm{M}_{2}$ and $\mathrm{M}_{3}$. P. simplex from Mirambueno 4C (Freudenthal et al., 1994) differs from $P$. cf. adroveri from Canales by its simpler dental pattern, which is most evident by the absence of a mesolophid in the $\mathrm{M}_{3}$.

$P$. thaleri from Coderet (Hugueney, 1969) has a more complex dental pattern than the material from Canales. The forward paracone spur is frequently present and the anterior arm of the protocone is directed towards the anterocone in $\mathrm{M}^{1}$. P. thaleri has also well-developed

\section{Plate II}

1-3 Adelomyarion sp. from Canales. 1. $\mathrm{M}^{2} \sin$. (CAN 126). 2. $M_{1}$ dext. (CAN 33). 3. $M_{3}$ sin. (CAN 39).

4-5 Adelomyarion cornelii (Freudenthal, 1994) from Canales. 4. $\mathrm{M}^{2}$ dext. (CAN 149). 5. $\mathrm{M}_{2}$ sin. (CAN 148).
6 Adelomyarion vireti Hugueney, 1969 from Parrales. 6. Anterior fragment of $\mathrm{M}^{\prime} \sin$. (PAR 73).

7 Heteroxerus sp. from Canales. $\mathrm{D}^{4}$ dext. (CAN 118).

The horizontal bar represents $1 \mathrm{~mm}$. 
Plate II
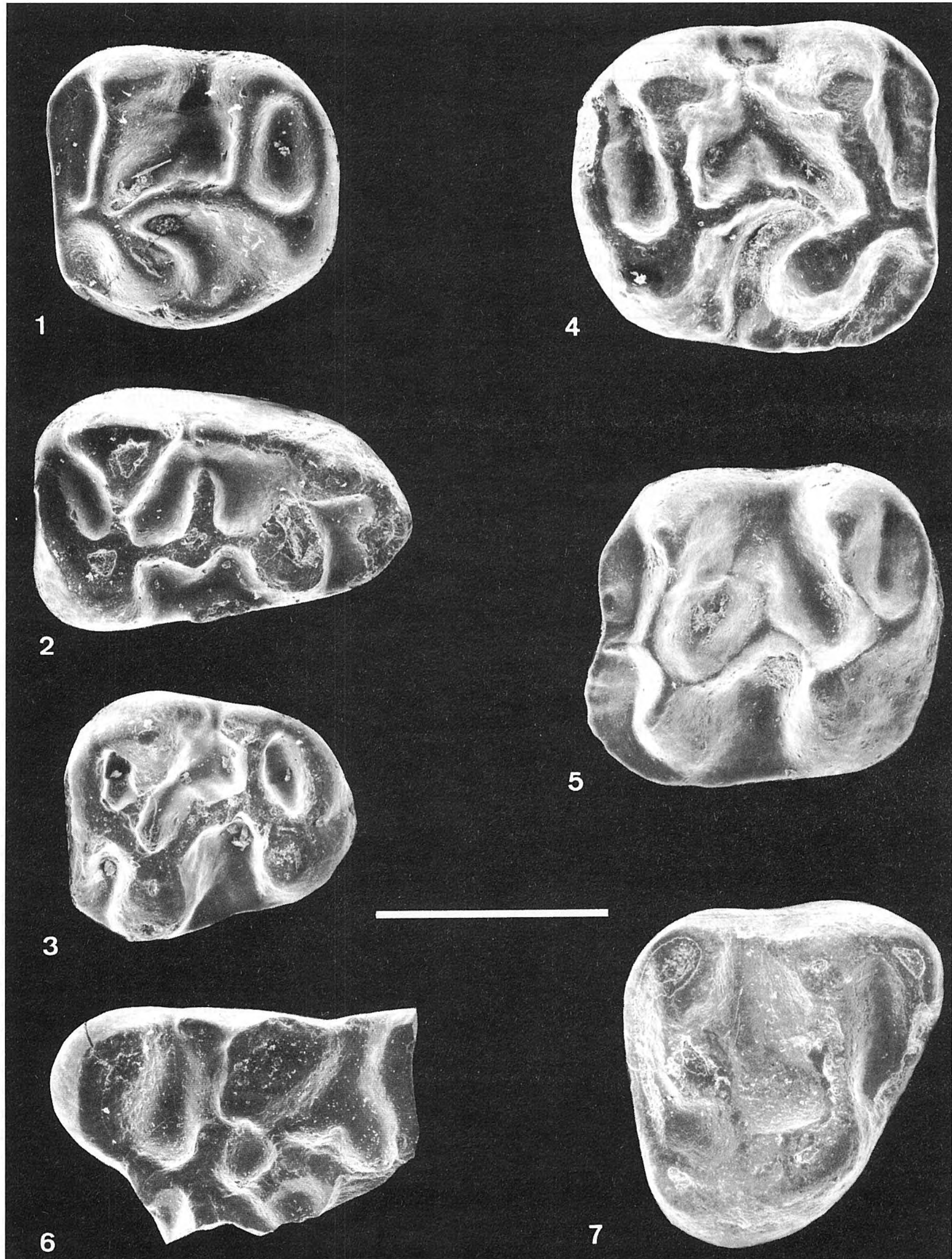


\begin{tabular}{|l|l|l|l|}
\hline Characters & Allocricetodon & Heterocricetodon & Adelomyarion \\
\hline Size & medium & large & medium \\
\hline $\begin{array}{c}\mathrm{M}_{1} \text { metaconid ridge } \\
\text { anterior metalophulid } \\
\text { lingual anterosinusid }\end{array}$ & $\begin{array}{l}\text { well-developed } \\
\text { absent } \\
\text { closed }\end{array}$ & $\begin{array}{l}\text { well-developed } \\
\text { absent } \\
\text { closed }\end{array}$ & $\begin{array}{l}\text { well-developed } \\
\text { absent } \\
\text { closed }\end{array}$ \\
\hline $\mathrm{M}_{1,2}$ posterosinusid & closed & closed & closed \\
\hline $\mathrm{M}_{3}$ posterior arm of protoconid & well-developed & well-developed & present \\
\hline $\begin{array}{c}\mathrm{M}^{1} \text { anterolophule } \\
\text { anterocone-paracone } \\
\text { connection }\end{array}$ & incomplete \\
frequently present & $\begin{array}{l}\text { incomplete } \\
\text { absent }\end{array}$ & $\begin{array}{l}\text { incomplete } \\
\text { absent/present }\end{array}$ \\
\hline $\begin{array}{l}\mathrm{M}^{1,2} \text { posterior wall of metacone- } \\
\text { metalophule complex }\end{array}$ & steep to vertical & steep to vertical & steep to vertical \\
\hline $\mathrm{M}^{2}$ outline & trapezoidal & subquadrate & subquadrate \\
\hline
\end{tabular}

Table 1. List of characteristic features of Allocricetodon, Heterocricetodon and Adelomyarion. The diagnostic characters of Allocricetodon were taken from Freudenthal (1994). The appreciation of features of the two other genera are according to the authors of this paper.

mesolophids and ectomesolophids in the lower molars. Not any of these characters are present in our material.

Morphologically the poor material from Canales falls inside the range of variation of $P$. adroveri from Vivel del Rio and Mirambueno 2A. However, since some of the diagnostical characters of the latter species could not be observed in our material we prefer to assign it to $P$. cf. adroveri.

Family Eomyidae Depéret \& Douxami, 1902

$$
\begin{gathered}
\text { Eomys cf. zitteli Schlosser, } 1884 \\
\text { Plate IV, figs. 12-18 }
\end{gathered}
$$

\section{Material and measurements:}

$$
\text { Length }
$$

$\begin{array}{lllll}D & 3 & 10.8 & 10.9 & 11.0\end{array}$

$\begin{array}{lllll}\mathrm{P}^{4} & 2 & 9.8 & 10.3 & 10.8\end{array}$

$\begin{array}{lllll}\mathrm{M}^{\prime} & 2 & 11.7 & 11.8 & 11.8\end{array}$

$\begin{array}{lllll}\mathrm{M}^{2} & 6 & 9.7 & 10.3 & 11.4\end{array}$

$\mathrm{M}^{1-2} \quad 1-10.8-$

$\mathrm{M}^{3} \quad 1-8.4-$

$\mathrm{D}_{4} \quad 0 \quad-\quad-$

$\begin{array}{lllll}\mathrm{P}_{4} & 4 & 10.2 & 10.8 & 11.4\end{array}$

$\begin{array}{lllll}\mathrm{M}_{1 \cdot 2} & 11 & 10.4 & 11.5 & 13.1\end{array}$

$\begin{array}{lllll}\mathrm{M}_{3} & 5 & 9.5 & 9.9 & 10.5\end{array}$

\begin{tabular}{rrrr}
\multicolumn{4}{c}{ Width } \\
$\mathrm{n}$ & min & mean & $\max$ \\
2 & 11.5 & 11.9 & 12.4 \\
1 & - & 11.7 & - \\
0 & - & - & - \\
2 & 12.5 & 13.5 & 14.6 \\
1 & - & 12.5 & - \\
1 & - & 11.3 & - \\
1 & - & 7.9 & - \\
3 & 9.3 & 9.9 & 11.0 \\
10 & 10.6 & 11.1 & 11.6 \\
5 & 9.5 & 10.1 & 10.7
\end{tabular}

\section{Description}

$D^{4}$ : Fairly bunodont teeth. The well-developed anteroloph measures approximately half of the tooth width. The mesoloph is absent in two specimens, it is short in two and it reaches the labial border in one. In two specimens there is a mesostyl near the paracone.

$\mathrm{P}^{4}$ : The short anteroloph ends labially free, and its lingual end joins the protoloph midway in 2 specimens. In one case the anteroloph is absent. The mesoloph is short in two specimens, and in the other one it reaches the labial border.

$M^{1,2}$ : The anteroloph is better developed in $M^{1}$ than it is in $\mathrm{M}^{2}$. The mesoloph is short in two specimens, of medium length in one, long without reaching the labial border in 4 , and it reaches the labial border in 8 cases.

$\mathrm{M}^{3}$ : The anteroloph is very small. The mesoloph is long and reaches the labial border. There is no sinus.

$\mathrm{D}_{4}$ : The long mesolophid reaches the lingual tooth border and the well-developed hypolophid connects entoconid to hypoconid.

$\mathrm{P}_{4}$ : Bunodont. The small anterolophid is lingually isolated and it may even be reduced to a tiny cusp. The mesolophid is absent in one specimen, it is short in two, of medium length in one, and in one case it is long and reaches the lingual tooth border. The short posterolophid ends free and does not reach the lingual tooth border.

$\mathrm{M}_{1,2}$ : Relatively bunodont. The lingual anterolophid is short to medium of length and it does not reach the lingual tooth border, with the exception of one specimen. The mesolophid is short in seven specimens, it is of medium length in four and in one specimen it is long and reaches the lingual border. The posterolophid is a well- developed ridge of medium length in 4 specimens, but in the other ones it is smaller.

$\mathrm{M}_{3}$ : The anterolophid is absent in one specimen. In the other specimens the lingual anterolophid is a short ridge which ends free lingually. The labial anterolophid is short and ends at the basis of the protoconid. The well-developed mesolophid joins the hypolophid, with the exception of one specimen. A posterolophid is absent.

\section{Discussion}

The assemblage of Eomys from Canales is morphologically and metrically homogeneous. Among the known Eomys-species only two have a size 
comparable to the one of our material from Canales: $E$. ebnatensis Engesser, 1987 from the Upper Oligocene of the Swiss Molasse and E. zitteli Schlosser, 1884 from the Upper Oligocene of western Europe. Specific separation between E. ebnatensis and E. zitteli is done on the basis of slight size differences, hypsodonty and morphology of premolars and lower molars (Engesser, 1987). E. ebnatensis from its type locality Ebnat (Engesser, 1987) is somewhat larger than E. cf. zitteli from Vivel del Río (Hugueney et al., 1987). The size ranges of our assemblage overlap with the ones of both above mentioned species. As for the dental pattern of the upper cheek teeth no significant differences could be observed between E. ebnatensis from Ebnat, Wynau 1 and Fornant 6 (Engesser, 1990), E. zitteli from the Quercy (Engesser, 1990), Vivel del Río (Hugueney et al., 1987) and E. cf. zitteli from Canales. In the lower cheek teeth are various morphological differences are observed however. Engesser (1987) mentioned that E. ebnatensis has better developed mesolophids and 4th lingual synclinids than $E$. zitteli. Our material from Canales has few long mesolophids such as is observed in E. zitteli from the Quercy and Vivel del Río, and the size of the 4th lingual synclinids falls within the range of variation of this species. Engesser $(1987,1990)$ explained that $E$. ebnatensis may be distinguished from the relatively bunodont $E$. zitteli by its more hypsodont teeth. Fresh or slightly worn teeth from Canales are relatively bunodont and agree more with those of E. zitteli. Summarizing, we think that morphologically (mesolophids, fourth lingual synclinids and bunodonty) our material is strongly related to E. zitteli, but since our material is not very abundant, we prefer to name it Eomys cf. zitteli.

\section{Family Zapodidae Coues, 1875}

\section{Plesiosminthus sp. \\ $1 \quad$ Plate $\mathrm{V}$, figs. 1-4}

\section{Material and measurements}

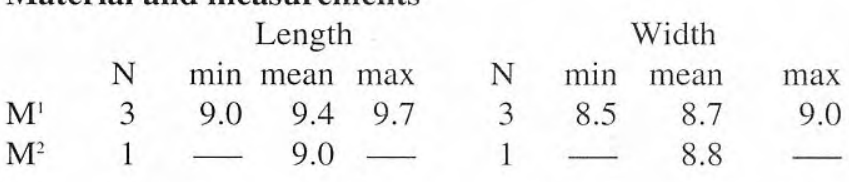

\section{Description}

$\mathrm{M}^{\prime}$ : The labial anteroloph is continuous, and in one specimen only a small anteroconule is distinct in this ridge. The lingual anteroloph is weakly developed and consists of a narrow style going straight down from the anteroconule to the crown basis. Labially the anterior valley is open. The entoloph is continuous. The protolophule is transverse in one specimen, and it points slightly forward in the other two. The mesoloph parts from the triangular mesocone and reaches the labial border. A mesostyl is indistinct. The metalophule is transverse. The posteroloph is labially isolated from the metacone. Lingually it is connected to the basis of the hypocone in one specimen, and it is separated from this cusp in the other two. A low cusp is present at the anterior wall of the hypocone. The sinus points sharply forward.
FRANCE

SPAIN

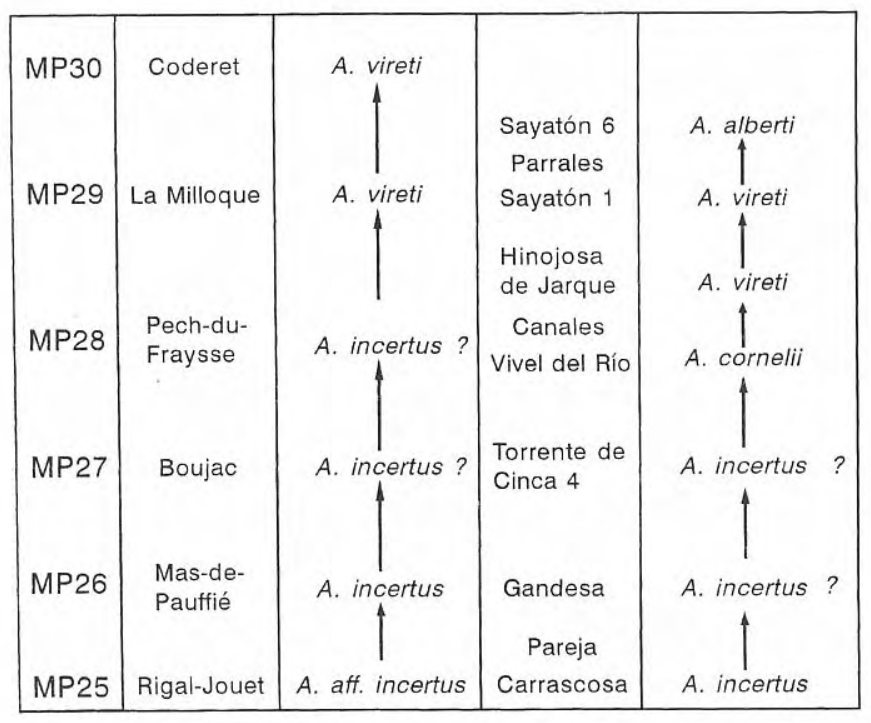

Figure 2. Phylogenetic hypothesis for Adelomyarion. Data from French localities from MP25-28 are from Comte (1985); from Gandesa and Torrente de Cinca 4 are from Agustí et al. (1985), (1987); from Carrascosa, Lacomba \& Morales (1987); from Pareja, Daams et al. (1989); other localities are cuoted in the discussion.

$\mathrm{M}^{2}$ : The long anteroloph is separated from the paracone, and an anteroconule is indistinct. The protolophule is transverse and the mesoloph is short in one specimen. In another, fragmentary specimen the protolophule is double. The anterior one is not complete and consists of a short oblique, free-ending, ridge sprouting from the anteroloph just before the protocone. The posterior protolophule runs from the paracone obliquely backward and joins the mesocone. In this fragmentary specimen the mesoloph is long. The metalophule is transverse and it joins the entoloph just before the hypocone. The posteroloph descends from the hypocone to the labial border where it is separated from the metacone. From the anterior border of the tooth a cingulum ridge descends along the lingual side and ascends to the anterior wall of the hypocone where it ends in a cusp. The sinus points sharply forward.

\section{Discussion}

Plesiosminthus sp. from Canales has smaller teeth than any hitherto known species of the genus. It differs from $P$. promyarion Schaub from the Upper Oligocene (MP29) of Pech Desse by the absence of an anteroconule in the anteroloph and by the absence of an extra cusp at the labial end of the anteroloph of $\mathrm{M}^{1}$. In Pech Desse the mesostyl of $\mathrm{M}^{\prime}$ is distinct, whereas this cusp is absent in Canales. In $\mathrm{M}^{2}$ of Pech Desse the endoloph is interrupted or weakly developed, while this ridge is continuous in Canales.

Plesiosminthus sp. from Canales differs morphologically from $P$. schaubi from Parrales by its continuous and well-developed anteroloph of $\mathrm{M}^{\prime}$, by its relatively smaller mesocone in $\mathrm{M}^{1.2 .}$ by the presence of a medium- 

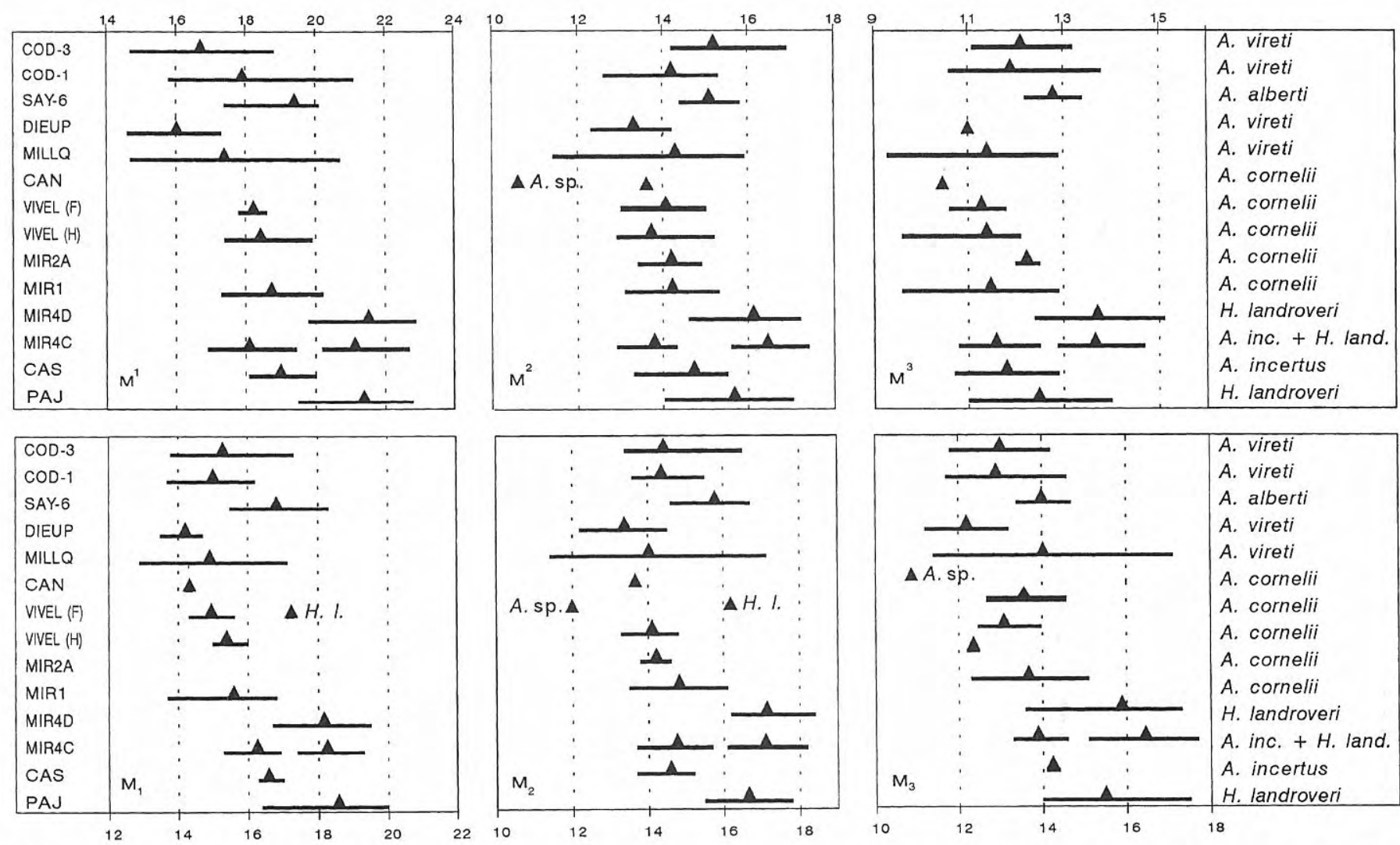

Figure 3. Length ranges of the molars of Adelomyarion and Heterocricetodon species from the Upper Oligocene of France (DIEUP, COD-1, COD-3, MILLQ), Germany (EHR7) and Spain (the remaining localities). Data of Coderet are from Hugueney (1969); Dieupentale from Baudelot \& Olivier (1978); Sayatón-6 from Daams (1989); La Milloque from Brunet (1979); Canales from this paper; Vivel del Río from Hugueney et al. (1987) and Freudenthal (1994); Mirambueno 1, 2A, 4C, 4D from Freudenthal (1994); Carrascosa from Lacomba \& Morales (1987); and Pareja from Daams et al. (1989). H. l. corresponds to Heterocricetodon landroveri.

long mesoloph in one $\mathrm{M}^{2}$, and by the double protolophule in another $\mathrm{M}^{2}$.

Until now three lineages of Plesiosminthus have been proposed. The first lineage is that of $P$. promyarion - $P$. myarion and it is among others characterized by the presence of the posterior arm of the protoconid in $\mathbf{M}_{1,2}$, and the frequent occurrence of double protolophules in $\mathrm{M}^{1,2}$ (Hugueney \& Vianey-Liaud, 1980). The second lineage would be that of $P$. morales $-P$. schaubi (Álvarez Sierra et al., 1996) in which the two above mentioned features are absent. The third lineage would be that of P. winistoerferi (Engesser, 1987) from the uppermost Oligocene of Switzerland characterized by its large size and the presence of a well-developed posterior arm of the protoconid in $\mathbf{M}_{2,3}$. The latter feature is considered to be a primitive character by Hugueney \& Vianey-Liaud (1980) and Engesser (1987) and it would point at a more primitive evolutionary stage than that of the much older $P$. promyarion. Plesiosminthus sp. from
Canales fits morphologically in the $P$. promyarion myarion lineage but its size is significantly smaller than that of $P$. promyarion from the more or less contemporaneous fissure fillings Pech Desse and Pech du Fraysse.

Family Gliridae Thomas ,1897

Peridyromys sp.

Pl. VI, figs. 1-8

\begin{tabular}{lrrrrrrrr}
\multicolumn{1}{c}{ Material and measurements: } \\
\multicolumn{9}{c}{ Length } \\
\multicolumn{1}{c}{$\mathrm{N}$} & min & mean & $\max$ & $\mathrm{N}$ & $\min$ & $\operatorname{mean}$ & $\max$ \\
$\mathrm{M}^{1}$ & 2 & - & 9.7 & - & 2 & 10.2 & 10.6 & 10.9 \\
$\mathrm{M}^{2}$ & 2 & 9.2 & 9.5 & 9.8 & 3 & 10.9 & 11.1 & 11.3 \\
$\mathrm{M}^{3}$ & 1 & - & 7.7 & - & 1 & - & 9.6 & - \\
$\mathrm{M}_{1}$ & 5 & 9.0 & 9.6 & 10.2 & 5 & 8.9 & 9.6 & 10.2 \\
$\mathrm{M}_{3}$ & 1 & - & 8.6 & - & 1 & - & 8.8 & -
\end{tabular}

\section{Plate III}

1-3 Pseudocricetodon cf. adroveri Freudenthal, Hugeney \&

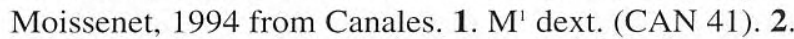
$\mathrm{M}^{2}$ dext. (CAN 124). 3. $\mathrm{M}_{3}$ dext. (CAN 40).
4-7 Eucricetodon cf. collatus (Schaub, 1925) from Parrales. 4. $M^{2}$ sin. (PAR 70). 5. $M_{1}$ dext. (PAR 67). 6. $M_{2}$ dext. (PAR 69). 7. $\mathrm{M}_{3}$ dext. (PAR 71).

The horizontal bar represents $1 \mathrm{~mm}$. 
Plate III

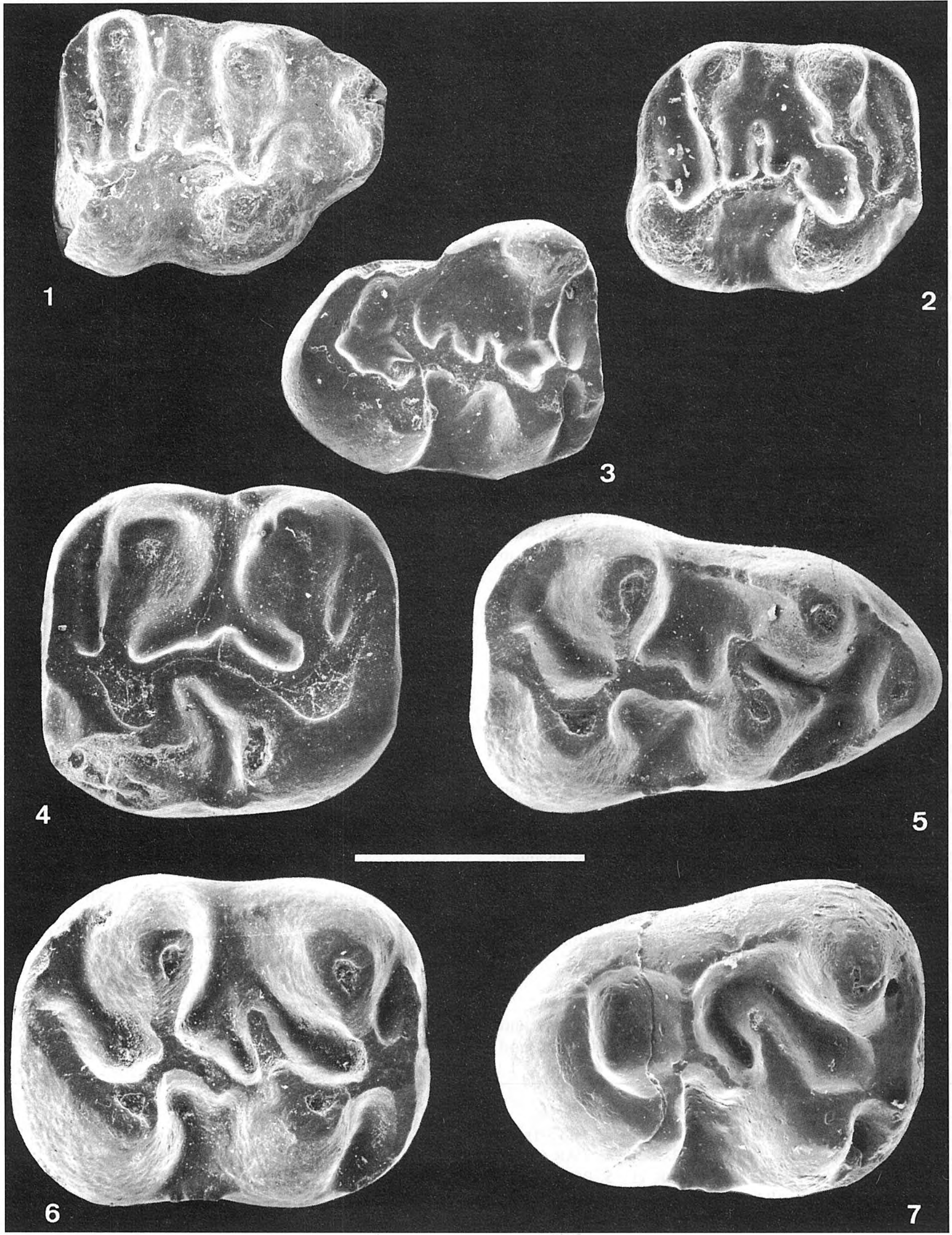

Revista Española de Paleontología, 14 (1), 1999. 


\section{Description}

The upper molars have a concave occlusal surface, the valleys are wide and the ridge slopes are gentle.

$\mathrm{M}^{\mathrm{1}}$ : One specimen has a centrally situated protocone, whereas it is situated more towards the postero-lingual border in the other two. The labial extension of the anteroloph joins the anterior wall of the paracone in one specimen and it is isolated in the other two. The anterior centroloph is connected to the paracone, and it is longer than the posterior centroloph. The posterior centroloph joins the metacone. The posteroloph is connected to the protocone, but is separated from the metacone by a shallow furrow. A tiny extra ridge is present between the protoloph and anterior centroloph. The posteroloph meets the protocone below the occlusal surface, and labially this ridge is separated from the metacone.

$\mathrm{M}^{2}$ : The anteroloph is an isolated ridge. The trigone has a symmetrical U-shape. The anterior centroloph is longer than the posterior one. Both ridges join paracone and metacone respectively. A tiny extra ridge is present between the protoloph and anterior centroloph in one specimen. The posteroloph meets the protocone and labially this ridge is separated from the metacone.

$\mathrm{M}^{3}$ : The anteroloph joins the protocone, thus forming a continuous endoloph. At its labial side the anteroloph is separated from the paracone. Two short centrolophs are present. One of these continues way into the central valley to form an irregularly shaped ridge. The anterior centroloph is connected to the paracone, but the posterior one is separated from the metacone. The posteroloph encloses the posterior valley.

$\mathrm{M}_{1}$ : Wide valleys and ridges. The anterolophid joins the protoconid in four out of five specimens. The metalophid is connected to the metaconid in two specimens and separated from this cusp in the other three. The short to medium-long centrolophid meets the metaconid. Mesolophid and posterolophid meet each other at the entoconid, which is a distinct cusp in one specimen. A tiny extra ridge is present in the posterior valley.

$\mathrm{M}_{3}$ : The anterolophid meets the protoconid. The metalophid is separated from the metaconid. The mediumlong centrolophid is somewhat shorter than in $\mathbf{M}_{1}$. The mesolophid is separated from the posterolophid at the lingual side by a deep furrow. A well-developed extra ridge is present in the posterior valley. One anterior root is present.

\section{Discussion}

Peridyromys sp. exhibits a mixture of primitive and modern features. The concave occlusal surface and centrally situated protocone of one $\mathrm{M}^{1}$ and the distinct entoconid of one $\mathrm{M}_{1}$ remind of Gliravus, but the complete mesolophid of $M_{1}$ and the generally well-developed ridges of all elements are typical of more evolved glirids. Peridyromys sp. from Canales is of the same size as Peridyromys murinus (Pomel) from the Lower Miocene of Spain but it has lower crowns and a slightly more complicated dental pattern. It is also slightly smaller than P. columbarii Daams, 1989 from the Upper Oligocene of Sayatón 6 (Daams, 1989), it has a more simple dental pattern, but the crown height is similar. Our material from Canales agrees both metrically and morphologically perfectly with Peridyromys murinus from the Upper Oligocene of St-Victor-la-Coste (Hugueney, 1968). However, we prefer to restrict $P$. murinus to those teeth which are relatively hypsodont and lacking extra ridges in most cases. Therefore we doubt if $P$. murinus from StVictor really corresponds to $P$. murinus, although the crown height of this assemblage has never been studied.

\section{Family Sciuridae Baird, 1857}

\section{Heteroxerus sp. Pl. II, fig. 7}

Material and measurements: $1 \mathrm{M}_{1-2}, 1 \mathrm{D}^{4}(1,18 \times 1,29)$.

\section{Description and discussion}

The preservation of the $\mathrm{M}_{1-2}$ is so bad that hardly any structure can be described. The $\mathrm{D}^{4}$ has a small hypocone in a more lingual position than the protocone. The posteroloph and metaloph are connected to the protocone. There is a large metaconule. The long posteroloph reaches the metacone.

The size and dental pattern of the $\mathrm{D}^{4}$ from Canales is similar to that of $H$. costatus (Freudenberg, 1941) from Gaimersheim (Kristkoiz, 1992). However the assignation of our material to the latter species is hazardous since only a deciduous tooth is available.

\section{PARRALES}

Family Theridomyidae Alston, 1876

\section{Issiodoromys pseudanaema (Gervais, 1848) Plate I, figs. 4,5}

Material and measurements: The few teeth present are broken and one specimen only $\left(\mathrm{M}_{3}, 17.1 \times 13.8\right)$ could be measured.

\section{Plate IV}

1-7 Rhodanomys hugueneyae Engesser, 1987 from Parrales. 1. $\mathrm{M}^{\prime}$ dext. (PAR 4). 2. $\mathrm{M}^{2}$ dext. (PAR 64). 3. $\mathrm{M}^{3}$ sin. (PAR 29). 4. $\mathrm{P}_{4}$ sin. (PAR 11). 5. $\mathrm{P}_{4}$ sin. (PAR 12). 6. $\mathrm{M}_{1-2}$ dext. (PAR 23). 7. $\mathrm{M}_{3}$ sin. (PAR 14).

8-11 Eomys huerzeleri Engesser, 1982 from Parrales. 8. $\mathrm{P}^{4}$ dext. (PAR 7). 9. $\mathrm{M}^{1-2}$ dext. (PAR 61). 10. $\mathrm{M}_{1-2}$ sin. (PAR 13). 11. $M_{3}$ sin. (PAR 24).
12-18 Eomys cf. zitteli Schlosser, 1884 from Canales. 12. $\mathrm{D}^{4}$ sin. (CAN 2). 13. $\mathrm{M}^{1} \sin .(\mathrm{CAN} 10) .14 . \mathrm{M}^{3} \sin$. (CAN 115). 15. $\mathrm{P}_{4}$ dext. (CAN 17). 16. $\mathrm{M}_{1-2}$ sin. (CAN 20). 17. $M_{1-2}$ sin. (CAN 19). 18. $M_{3}$ sin. (CAN 26).

The horizontal bar represents $1 \mathrm{~mm}$. 

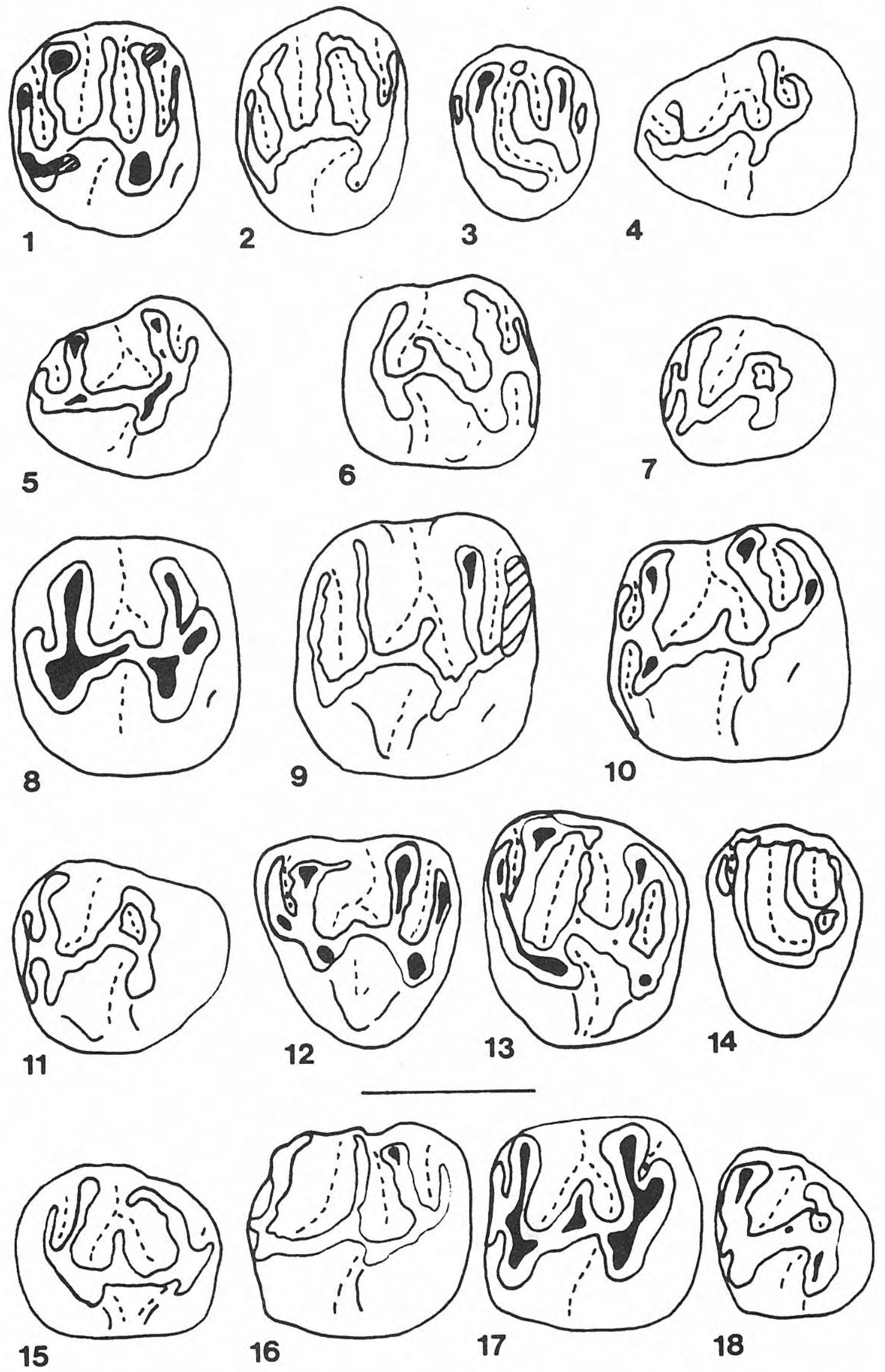


\section{Discussion}

The most characteristic features of this material are its high degree of hypsodonty ( 3 of one specimen of $\mathrm{M}_{1,2}$ ), and the absence of roots in rather worn specimens. These two features are only present in I. pseudanaema and in $I$. bransatensis Schmidt-Kittler \& Vianey-Liaud, 1987. Although the fragmentary material could not be measured, with the exception of one $\mathrm{M}_{3}$, it is apparent that the size of the teeth is larger than that of $I$. bransatensis from Coderet (Hugueney, 1969; SchmidtKittler \& Vianey-Liaud, 1987). Other peculiar features are the presence of enamel at the lingual side of the lower cheek teeth, and the lesser curvature of the upper cheek teeth. In the teeth from Coderet the enamel becomes rapidly lost and the upper cheek teeth are more curved.

Family Cricetidae Rochebrune, 1883

\section{Eucricetodon cf. collatus (Schaub, 1925) Pl. III, figs. 4-7}

Material and measurements: $\mathrm{M}^{1}(-\mathrm{x}-) ; \mathrm{M}^{2}(16.0 \times 14.7)$; $\mathrm{M}_{1}(18.9 \times 12,5) ; \mathrm{M}_{2}(16.7 \times 13.5) ; \mathrm{M}_{3}(16.8 \times 13.2)$.

\section{Description}

$\mathrm{M}^{\prime}$ : The simple, bean-shaped anterocone is situated somewhat lingually. The labial and lingual parts of the anterocone descend to reach the bases of paracone and protocone respectively. The anterior arm of the protocone points obliquely forward and ends free near the anterolingual basis of the paracone. A short mesoloph is present. The remaining part of the tooth is missing.

$\mathrm{M}^{2}$ : The labial anteroloph joins the basis of the paracone, thus closing the anterosinus. A lingual anteroloph is absent. A mesoloph is absent. The sinus points sharply forward. The wide posteroloph joins the basis of the metacone, thus closing the narrow posterosinus.

$M_{1}$ : The posterior arm of the protoconid runs obliquely backward to turn transversely to join the postero-labial basis of the metaconid. The entolophid joins the posterior wall of the protoconid about halfway. A mesolophid is absent. From the top of the metaconid a crest descends along the lingual border toward the entoconid but without reaching this cusp. The posterolophid runs along the posterior border of the tooth and ascends toward the top of the entoconid, thus closing the posterosinusid. A hypoconulid is distinct in the posterolophid.

$\mathrm{M}_{2}$ : The lingual anterolophid is medium long and encloses the narrow, lingual anterosinusid. The labial anterolophid descends to meet the basis of the protoconid. The well-developed, posterior arm of the protoconid ends free in the mesosinusid. The entolophid is oblique and joins the posterior wall of the protoconid just below the occlusal surface. The posterolophid widens behind the hypoconid, indicating the hypoconulid, but then becomes narrow to join the basis of the entoconid, thus bordering the posterosinusid.

$\mathrm{M}_{3}$ : The lingual anterolophid is medium long and encloses the narrow, lingual anterosinusid. The welldeveloped, posterior arm of the protoconid ends free in the mesosinusid. The entolophid is oblique and joins the anterior wall of the protoconid just below the occlusal surface. A relatively high ridge is present between the top of the entoconid and the posterior wall of the metaconid, thus bordering the mesosinusid.

\section{Discussion}

The size of the teeth of $E$. cf. collatus from Parrales falls within the size ranges of $E$. collatus, E. longidens Hugueney, 1969 and E. hesperius Engesser, 1985 although the length of our $M_{1}$ is closer to the mean value of those of E. longidens from Coderet than that of $E$. collatus from Küttigen. The length of $\mathrm{M}_{3}$ of $E$. cf. collatus from Parrales exceeds the size range of E. collatus from Küttigen, but falls within the size range of $E$. longidens from Coderet according to the size ranges given by Hugueney (1969). In Engesser (1985) the size ranges of the Küttigen material are somewhat larger, so that our $\mathrm{M}_{3}$ from Parrales falls more or less in the size range of $E$. collatus. The $\mathrm{M}_{1}$ falls within the morphological variation of $E$. longidens, and our $\mathrm{M}_{2}$ may correspond to either species. Morphologically our material fits less with $E$. hesperius from Paulhiac (Engesser, 1985) by the badly developed mesoloph(id)s. On the other hand, the differences between $E$. longidens an E. collatus are so small that specific separation is questionable. Our poor material does not correspond to E. praecursor because of its larger size and its more evolved dental pattern (absence of posterior arm of the hypoconid in $\mathrm{M}_{1}$ and $\mathrm{M}_{2}$ ).

The few teeth of Eucricetodon gr. praecursor-collatus from the Upper Oligocene (MP29) of Hinojosa de Jarque 2 (Cuenca \& Canudo, 1994) should probably be assigned to E. praecursor since the $\mathrm{M}_{2}$ has a well-developed posterior arm of the hypoconid.

\section{Adelomyarion vireti Hugueney, 1969 Pl. II, fig. 6}

\section{Description and discussion}

Only one fragmentary $\mathrm{M}^{1}$ is present. The simple and bean-shaped anterocone joins the protocone lingually. At the anterior wall of the paracone a narrow spur descends along the labial border without reaching the anterocone. The protocone has a transverse anterior arm which joins the paracone. An oblique ridge is present between the labial wall of the protocone and the endoloph. The

\section{Plate V}

1-4 Plesiosminthus sp. from Canales. 1. $\mathrm{M}^{1}$ dext. (CAN 55). 2. $\mathrm{M}^{1}$ dext. (CAN 57). 3. $\mathrm{M}^{1} \sin$. (CAN 54). 4. $\mathrm{M}^{2} \sin$. (CAN 129).

5-11 Plesiosminthus schaubi Viret, 1926 from Parrales. 5.

$\mathrm{M}^{1} \sin$. (PAR 40). 6. $\mathrm{M}^{1} \sin$. (PAR 25). 7. $\mathrm{M}^{2} \sin$. (PAR 56). 8. $M^{2}$ sin. (PAR 31). 9. $M_{2}$ dext. (PAR 49). 10. $M_{1}$ dext. (PAR 45). 11. $\mathrm{M}_{1}$ dext. (PAR 44).

The horizontal bar represents $1 \mathrm{~mm}$. 


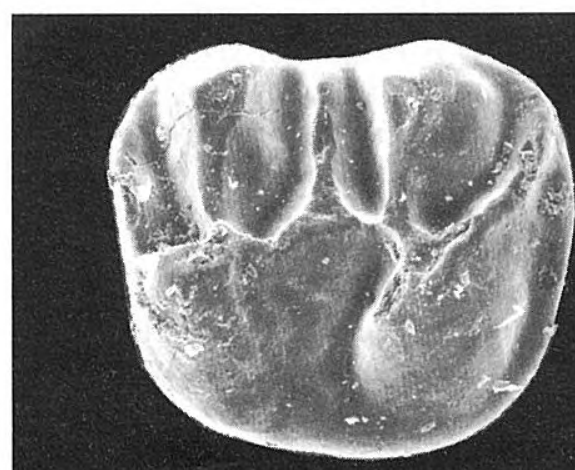

1

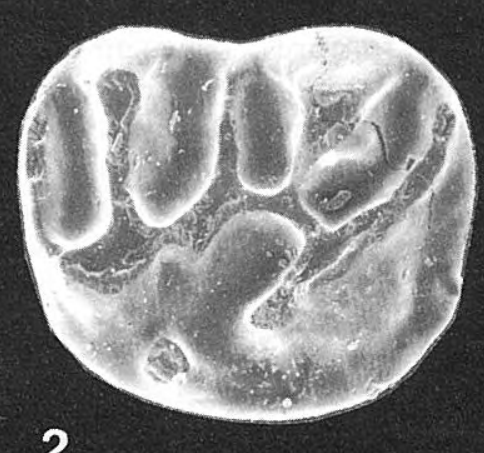

2

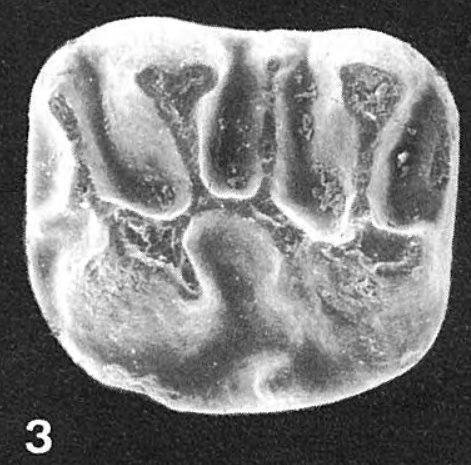

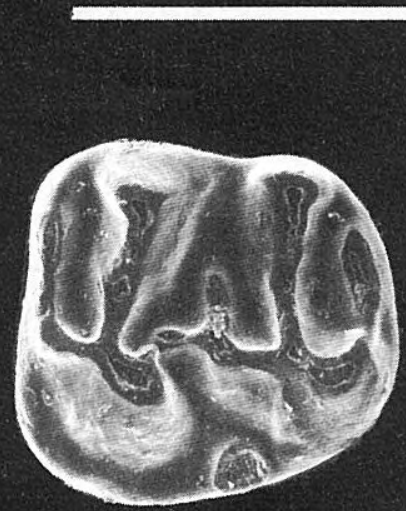

4

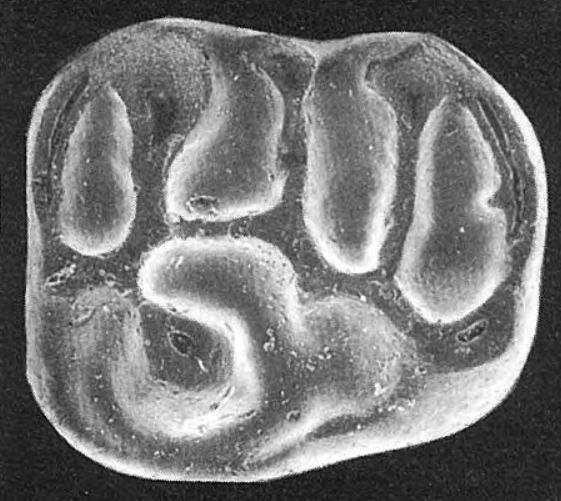

7
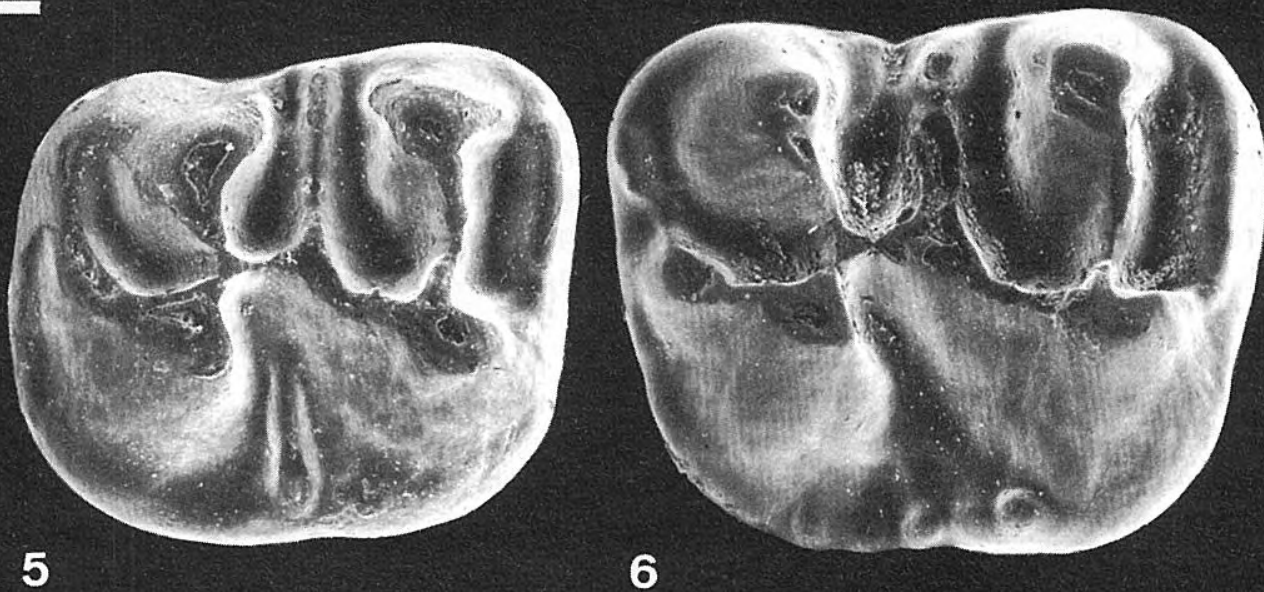

6

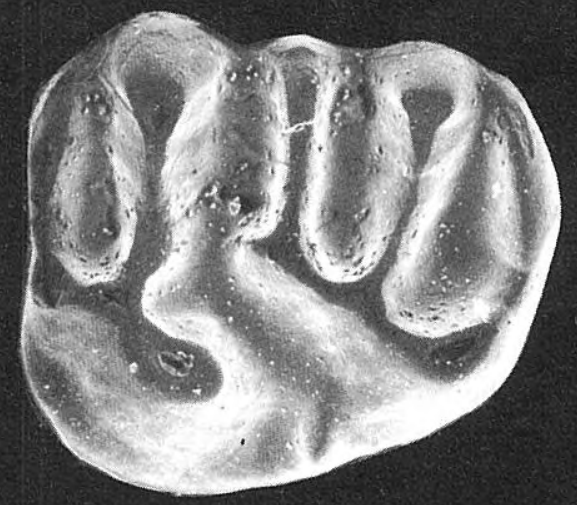

8

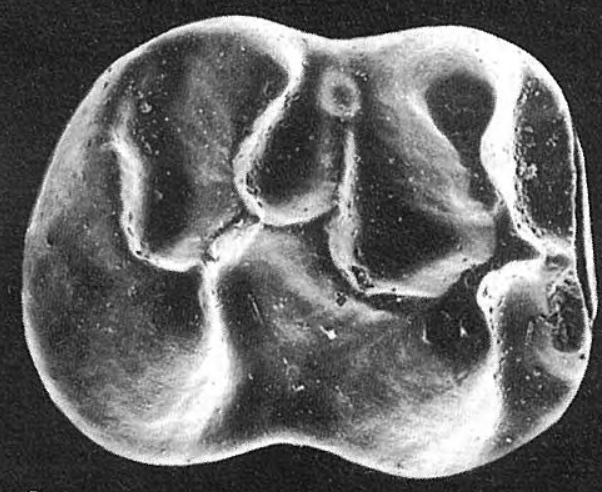

9
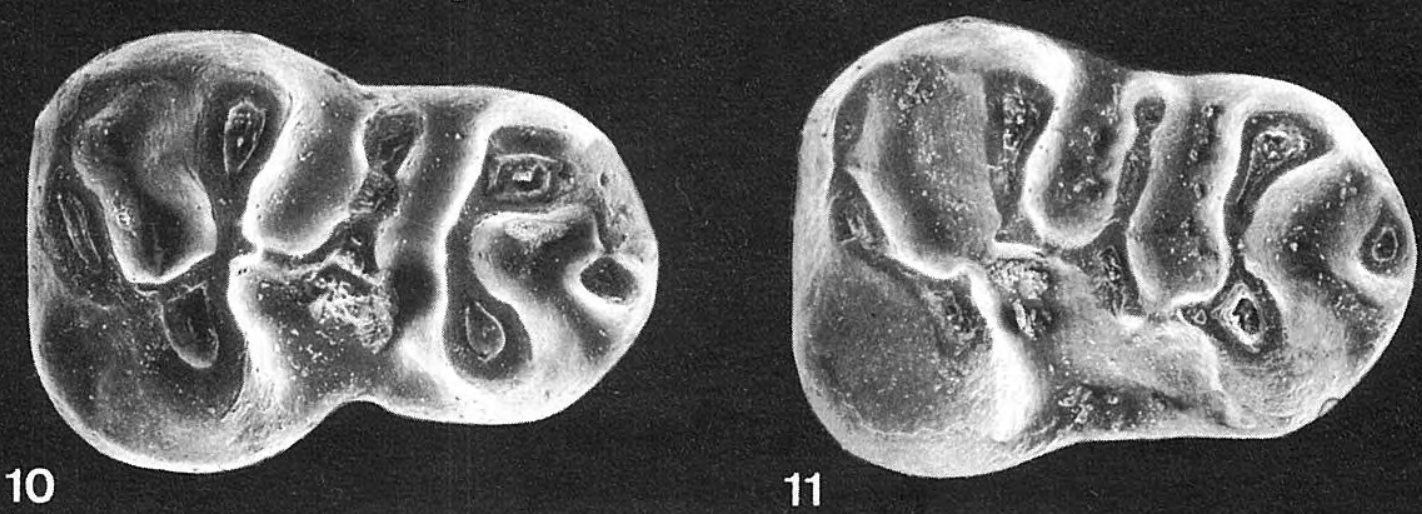
inflated endoloph meets the postero-lingual basis of the paracone. A mesoloph is absent. The estimated size of this fragment agrees with that of the various Adelomyarion vireti assemblages. The fact that the strongly forward pointing protolophule is connected to the anterior arm of the protocone would point at a more evolved stage than that of A. cornelii from Canales, and it would fall inside the range of variation of $A$. vireti.

\section{Family Eomyidae Depéret \& Douxami, 1902}

\section{Eomys huerzeleri Engesser, 1982 Pl. IV, figs. 8-11}

\section{Material and measurements:}

\begin{tabular}{lrrrrrrrr}
\multicolumn{4}{c}{ Length } & \multicolumn{9}{c}{ Width } \\
& $\mathrm{n}$ & $\min$ & $\operatorname{mean}$ & $\max$ & $\mathrm{n}$ & $\min$ & $\operatorname{mean}$ & $\max$ \\
$\mathrm{P}^{4}$ & 2 & 12.3 & 12.5 & 12.7 & 2 & 13.9 & 14.0 & 14.2 \\
$\mathrm{M}^{1}$ & 2 & 13.2 & 13.2 & 13.2 & 1 & - & 16.6 & - \\
$\mathrm{M}^{2}$ & 2 & 11.7 & 12.0 & 12.4 & 1 & - & 15.9 & - \\
$\mathrm{M}_{1,2}$ & 4 & 12.9 & 13.8 & 14.4 & 4 & 13.6 & 13.9 & 14.4 \\
$\mathrm{M}_{3}$ & 1 & - & 11.7 & - & 1 & - & 12.3 & -
\end{tabular}

\section{Description}

$\mathrm{P}^{4}$ : The anteroloph is absent in one specimen, and in the other it is short and wide. A mesoloph is absent. The posteroloph is very short in one specimen, and in the other it is longer, but without reaching the labial tooth border.

$\mathrm{M}^{1,2}$ : The anteroloph is well-developed. The mesoloph is short in three and of medium length in two specimens. One specimen has a low mesostyl. The posteroloph descends from the hypocone toward the labial border where it ends free just before reaching it.

$\mathrm{M}_{1,2}$ : The anterolophid consists of labial and lingual part . The mesolophid is short in one specimen, of medium length in two, and long without reaching the lingual tooth border in one specimen. The posterolophid is absent in two specimens. When it is present, it is well developed.

$\mathrm{M}_{3}$ : The anterolophid is narrow and consists of a lingual and a labial part. The short mesolophid joins the reduced entoconid in one specimen and it is separated from this cusp in the other. A posterolophid is absent.

\section{Discussion}

E. huerzeleri from Parrales has on the average smaller teeth than E. gigas Comte \& Vianey-Liaud, 1987 from the Upper Oligocene of Pech du Fraysse. Our material agrees both metrically and morphologically with $E$. huerzeleri from the Swiss Molasse (Engesser, 1982 and 1990). According to Engesser (1982) this species is characterized by four-rooted $\mathrm{M}_{1,2}$, short to medium-long mesoloph(id)s that never reach the tooth border, hypsodont teeth which is most distinct at the lingual part of the $M^{1.2}$ and a well-developed anterosinus of $M^{1.2}$. Except that we cannot observe the number of roots in any $M_{1,2}$, the remaining features agree well with our material from Parrales.

E. cf. huerzeleri from MP29 of Sayatón 1 (Álvarez Sierra et al., 1996) is of the same size as our material from Parrales, although the $\mathrm{P}^{4}$ from Parrales if longer. Eomys aff. huerzeleri from Hinojosa de Jarque 2 (MP29, Cuenca \& Canudo, 1994) is of similar size and dental pattern as our material and both assemblages fall inside the range of variation of E. huerzeleri from its type locality Rickenbach. E. aff. huerzeleri from MP29 of Verneuil, France (Hugueney, 1984) is of smaller size than E. huerzeleri from Rickenbach and the Spanish localities. It has four-rooted $\mathrm{M}_{2}$ like the type material, which made Hugueney (1984) consider the Verneuil assemblage to be ancestral to the one from Rickenbach.

\section{Rhodanomys hugueneyae Engesser, 1987 Pl. IV, figs. 1-7}

\begin{tabular}{|c|c|c|c|c|c|c|c|c|}
\hline \multicolumn{9}{|c|}{ Material and measurements: } \\
\hline & $\mathrm{n}$ & $\min$ & mean & $\max$ & & $\min$ & mean & $\max$ \\
\hline$M^{1}$ & 1 & - & 11.5 & - & 1 & - & 12.6 & \\
\hline$M^{2}$ & 3 & 9.3 & 9.7 & 10.2 & 2 & 11.8 & 12.1 & 12.5 \\
\hline $\mathrm{M}^{3}$ & 1 & - & 8.2 & - & & - & 10.0 & \\
\hline $\mathrm{P}^{4}$ & 2 & 11.0 & 11.6 & 12.3 & & 10.5 & 10.5 & 10.5 \\
\hline $\mathrm{M}_{1,2}$ & 3 & 10.5 & 11.3 & 11.8 & & 10.9 & 11.3 & 11.7 \\
\hline $\mathrm{M}_{3}$ & 1 & - & 9.1 & - & 1 & - & 9.3 & \\
\hline
\end{tabular}

\section{Description}

$\mathrm{M}^{1.2}$ : The anteroloph and posteroloph are narrower and lower than the other ridges. In all four specimens the mesoloph is long and reaches the labial tooth border.

$\mathrm{M}^{3}$ : The anteroloph is a short, narrow and low ridge stuck to the anterior border of the tooth. The mesoloph is long and it is separated from the metacone by a furrow. The posteroloph is badly developed.

$\mathrm{P}_{4}$ : The anterolophid is very short . The mesolophid is short in one specimen and absent in the other.

$\mathrm{M}_{1,2}$ : The lingual anterolophid is of medium length in two and long in the other two specimens. The labial part of the anterolophid is better developed than the lingual part. The mesolophid is short in one specimen and of medium length in the other three. A posterolophid is absent.

$\mathrm{M}_{3}$ : The anterolophid is badly developed. The mesolophid joins the entoconid. A posterolophid is absent.

\section{Discussion}

The evolutionary trends of the Rhodanomys Ritteneria lineage are toward smaller teeth and reduction and the loss of various ridges like anteroloph(id)s, mesoloph(id)s, posteroloph(id)s and longitudinal ridges. (Hugueney, 1969; Álvarez Sierra, 1987; Engesser, 1987, 1990 amongst others).

The material from Parrales shows primitive features like well-developed anterolophs and mesolophs in all upper molars, a continuous longitudinal ridge (except in one specimen), and a short to medium-long mesolophid in all $\mathrm{M}_{1,2}$. Morphologically our assemblage is similar to the two oldest representatives of Rhodanomys: Rh. hugueneyae Engesser, 1987 from the Upper Oligocene of Spain and Switzerland and Rh. transiens Hugueney, 1969 
from the Upper Oligocene of Spain, France, Germany and Switzerland.

According to Engesser 1987, 1990 Rh. hugueneyae has larger teeth than $R h$. transiens, it has better developed anterolophs, longer mesolophids, and more frequently a posterolophid in $\mathrm{M}_{1,2}$. Both species have teeth with primitive features on the one hand, and some more evolved characters on the other. The difference between the two species lies in the relative abundance of these features. For instance, the posterolophid is present in $55.5 \%$ of $\mathrm{M}_{1,2}$ of $R h$. hugueneyae from Küttigen, in $31.5 \%$ of $\mathrm{M}_{1,2}$ of $R h$. aff. hugueneyae from Brochene Fluh 53 and in Rh. transiens from Bergasa, Coderet and Sayatón 6 these numbers are $20 \%, 28.5 \%$ and $19 \%$ respectively. As Rh. hugueneyae evolves gradually into $R h$. transiens, we need wellrepresented populations to obtain reliable determinations.

Our material has short to medium-long mesolophids and the posterolophid is absent in all lower molars. Specimens with short or medium long mesolophids are present in both species but they are more frequent in $R h$. transiens. On the other hand, all upper molars of Rhodanomys from Parrales have a well-developed anteroloph, which is a primitive feature frequent in $R h$. hugueneyae. Considering the evolutionary trends of this lineage we conclude that our assemblage is slightly older than the ones of Rh. transiens, especially because of the well-developed anterolophs. Unfortunately the material attributed to Rh. hugueneyae by Engesser $(1987,1990)$ is not abundant, hampering a good comparison, but the absence of posterolophids and the shorter mesolophids of $\mathrm{M}_{1,2}$ in our assemblage from Parrales may indicate that our material is slightly more evolved.

The size of the teeth of our material falls within the size ranges of $R h$. transiens from the Upper Oligocene of Coderet (Hugueney, 1969), Bergasa (Álvarez Sierra, 1987), Sayatón 6 (Daams, 1989) and Les Pierrettes (Engesser, 1990). Only the size of our $\mathrm{P}_{4}$ appears to be slightly larger. The teeth from Parrales are slightly smaller than those of Rh. hugueneyae from Küttigen, Brochene Fluh $19 / 20$ and $R h$. aff. hugueneyae from Brochene Fluh 53 and Findreuse 8 (see Engesser, 1990). Rh. hugueneyae from Parrales is of similar size as the same species from Sayatón 1 (Álvarez Sierra et al., 1996) with the exception of the larger $\mathrm{P}_{4}$ of Parrales.

Considering the morphological and metrical features discussed above, we may conclude that the assemblage from Parrales is more evolved than the ones of $R h$. hugueneyae from the Upper Oligocene of Switzerland, but they are slightly less evolved than the ones of $R h$. transiens from Bergasa and Coderet. Rh. transiens from the Upper Oligocene of Sayatón 6 (Daams, 1989) may represent a more evolved stage.

In Parrales Rh. hugueneyae is associated with a largesized eomyid (Eomys huerzeleri) like in Sayatón 1. According to Engesser $(1987,1990)$ E. huerzeleri concurs with $R h$. hugueneyae in various localities from the swiss Upper Oligocene like Rances, La Cornalle, Brochene Fluh 4/5 and 19/20 and Basel Skt Jakob. These localities are situated between the levels of Rickenbach (MP29) and Küttigen (MP30).
Family Zapodidae Coues, 1875

$$
\begin{gathered}
\text { Plesiosminthus schaubi Viret, } 1926 \\
\text { Pl. V, figs. 5-11 }
\end{gathered}
$$

\begin{tabular}{|c|c|c|c|c|c|c|c|c|}
\hline & \multicolumn{5}{|c|}{ Length } & \multicolumn{3}{|c|}{ Width } \\
\hline & $\mathrm{n}$ & $\min$ & mean & $\max$ & $\mathrm{n}$ & $\min$ & mean & $\max$ \\
\hline$M^{1}$ & 13 & 10.9 & 12.2 & 13.7 & 13 & 9.8 & 11.2 & 12.2 \\
\hline $\mathrm{M}^{2}$ & 14 & 10.1 & 11.0 & 11.7 & 14 & 9.1 & 10.6 & 11.8 \\
\hline $\mathrm{M}^{3}$ & 2 & 7.9 & 8.3 & 8.7 & 2 & 8.3 & 8.9 & 9.5 \\
\hline$M_{1}$ & 15 & 11.7 & 12.8 & 14.4 & 16 & 8.6 & 9.4 & 11.2 \\
\hline $\mathrm{M}_{2}$ & 13 & 10.3 & 11.9 & 13.5 & 16 & 8.4 & 9.6 & 11.1 \\
\hline $\mathrm{M}_{3}$ & 2 & 8.4 & 8.9 & 9.4 & 3 & 8.1 & 8.5 & 8.8 \\
\hline
\end{tabular}

Material and measurements:

\section{Description}

$\mathrm{M}^{\prime}$ : The anteroloph is continuous and nearly reaches the labial border in 10 specimens and it is interrupted at about $1 / 3$ of the tooth width from the labial border in 3 specimens. An anteroconule is distinct in the anteroloph in 5 out of 13 specimens. The interruption of the anteroloph is behind the anteroconule, and the labial part consists of a short and elongated cusp-like ridge. The connection between the protocone and paracone is variable. In 2 specimens the protolophule is transverse and it joins the protocone directly. In 9 specimens the protolophule points obliquely backward and meets the entoloph just behind the protocone. In one specimen the entoloph is interrupted so that the sinus forms a continuous valley with the valley between the anteroloph and paracone. In another specimen the entoloph breaks more toward the back so that the sinus forms a continuous valley with the anterior mesosinus. The sinus points strongly forward. The mesoloph parts from the well-developed, triangular mesocone and reaches the labial border in 12 specimens, where it ends in a mesostyl in 8 . In 2 specimens the mesoloph is of medium length and it does not reach the mesostyl. The metalophule may be slightly curved, and it meets the hypocone transversely. The posteroloph is low and it does not join the metacone. Lingually this ridge may be either isolated from the hypocone (in 5 specimens) or it may join the basis of this cusp (in 9 cases). In one specimen the sinus does not have an additional ridge but in the other 13 there is a ridge of variable aspect. It may be a cusp at the lingual border (in 5 specimens); it may be a longitudinal ridge (in 6); or a more or less transverse ridge (in 2 ). In one specimen this longitudinal ridge continues into a cingulum bordering the antero-lingual part of the molar.

$\mathrm{M}^{2}$ : A distinct anteroconule is present in the anteroloph in 11 out of 16 specimens. Labially the anteroloph does not join the paracone. The protolophule points slightly backward or it is transverse and it joins the anteroloph just after parting from the protocone. The entoloph is interrupted in 7 out of 18 specimens so that the sinus and the anterior mesosinus form a continuous valley. The mesoloph parts from the triangular mesocone and reaches the labial border in all specimens. The mesostyl is less distinct than in $\mathrm{M}^{1}$ or not distinct at all. The sinus points strongly forward. The metalophule is transverse or it points slightly forward, and it joins the entoloph just before the hypocone. The posteroloph sprouts from the top of the hypocone and it may or may not 
be connected to the basis of the metacone. On the anterolingual wall of the hypocone a low cusp is present in 9 specimens. In 2 specimens this cusp is longitudinally elongated and directed toward the top of the hypocone. In 2 specimens a cingulum ridge runs from the anteroconule along the lingual border to the basis of the hypocone, thus separating the protocone from the lingual border. In 2 specimens there is a transverse ridge in the sinus and in 3 other specimens the sinus is void of cusps or ridges.

$\mathrm{M}^{3}$ : The sinus is closed in one, and open in the other specimen. The mesoloph is long in both specimens.

$\mathrm{M}_{1}$ : The anteroconid is an isolated, round or transversely somewhat elongated cusp in 14 specimens; it is connected to the protoconid in one, and it joins the metaconid in 2 specimens. The furrow separating the anteroconid from the protoconid is deeper than the one between anteroconid and metaconid. The protoconid and metaconid meet each other transversely or the meeting point of these two cusps lies somewhat more backward. From the well-developed triangular mesoconid a long and low mesolophid extends to the lingual border where it ends in a small, but distinct mesostylid. In one specimen only the mesolophid is interrupted before reaching the mesostylid. The entolophid connects the mesoconid with the protoconid in 13 specimens, and in 4 specimens the entolophid is interrupted or absent at this place. In one specimen a low longitudinal connection is present between the mesolophid and the protoconid-metaconid junction. The posterior part of the entolophid is generally well developed and it is connected to the meeting point of hypo- and entoconid in 12 specimens; it joins the entoconid in 2; it meets the hypoconid in 2 and it is absent in one case. The transverse hypolophulid is connected to the entolophid before the hypoconid in 12 specimens; in 3 specimens the hypolophulid joins the anterior part of the hypoconid, and in 2 specimens the hypolophulid points backward and meets the hypoconid in the middle. The posterolophid widens behind the hypoconid to form an elongated hypoconulid in 13 out of 17 specimens. The posterolophid reaches the lingual border where it curves round to mount the entoconid, thus closing the posterior valley. In one specimen the posterolophid is interrupted between hypoconid and hypoconulid. In 8 out of 17 specimens a weak to moderately developed ridge goes down from the hypoconulid toward the postero-labial basis of the hypoconid.

$\mathrm{M}_{2}$ : Both the lingual and labial anterolophid are well developed, and they part from the anterolophulid. In one specimen the anterolophid is an isolated ridge because of the absence of the anterolophulid. The lingual anterolophid ends at the basis of the metaconid. The labial part ends at the basis of the protoconid in 10 specimens and in 6 it continues as a cingulum ridge ending at the basis of the hypoconid. The metalophulid meets the anterolophulid just before the protoconid in 13 cases, and in 2 specimens the metalophulid and protoconid meet each other transversely. The oblique entolophid runs between protoconid and entoconidhypoconid meeting point. The mesolophid is long and ends at the lingual border in a slightly distinct or indistinct mesostylid in 14 specimens. In one case the mesolophid is of medium length and a mesostylid is absent, and in another specimen the mesolophid is of medium length but a mesostylid is present. The hypolophulid meets the entolophid before the hypoconid. The posterolophid is constricted just behind the hypoconid, but then widens to form a hypoconulid in 9 specimens. In the other 5 the hypoconulid is not or hardly distinct. The posterolophid joins the basis of the entoconid, thus closing the posterior valley.

$\mathrm{M}_{3}$ : The lingual anterolophid is relatively short, but the labial one reaches the basis of the protoconid. The short anterolophulid joins the protoconid-metaconid connection. A short, oblique mesolophid is present.

\section{Discussion}

P. schaubi from Parrales is of the same size as the same species from Coderet (Hugueney, 1969). Only the $\mathrm{M}^{3}$ from Parrales is slightly larger. The morphology of the upper molars from Parrales agrees perfectly with that of the upper molars from Coderet. Some slight differences are observed in the lower molars. In Parrales the anteroconid of $M_{1}$ is generally isolated, whereas in Coderet this cusp joins the metaconid in most cases. Another difference is that in Parrales the mesoconid is connected to the protoconid in nearly all specimens, whereas in Coderet this connection does not exist in the major part of the specimens. We do not know if these differences are due to geographical provincionality, or to (slight) evolutionary differences.

\section{Family Gliridae Thomas, 1897}

\section{Peridyromys murinus (Pomel, 1853) Pl. VI, fig. 9}

\section{Material and measurements: $1 \mathrm{M}^{1}(8.6 \times 10.6)$.}

\section{Description and discussion}

Relatively hypsodont. The protoloph meets the metaloph somewhat inside the tooth. The posteroloph joins the protocone, but it is isolated from the paracone.

\section{Plate VI}

1-8 Peridyromys sp. from Canales. 1. $\mathrm{M}^{1}$ dext. (CAN 49). 2. $\mathrm{M}^{2}$ dext. (CAN 57). 3. $\mathrm{M}^{1}$ dext. (CAN 161). 4. $\mathrm{M}^{3} \sin$. (CAN 48). 5. $M_{1}$ dext. (CAN 163). 6. $M_{1}$ dext. (CAN 164). 7. $M_{1}$ dext. (CAN 47). 8. $M_{3}$ sin. (CAN 46).

9 Peridyromys murinus (Pomel, 1853) from Parrales. $\mathrm{P}^{4}$ sin. (PAR 201).
10-13 Armantomys cf. bijmai (Lacomba \& MartínezSalanova, 1988) from Parrales. 10. $\mathrm{M}^{\prime} \sin$. (PAR 200). 11. $M_{2}$ dext. (PAR 203). 12. $M_{1}$ dext. (PAR 206). 13. $M_{3}$ dext. (PAR 205).

14-15 Gliridae indet. from Parales. 14. $M_{2}$ sin. (PAR 204). 15. $\mathrm{M}^{3}$ dext. (PAR 202).

The horizontal bar represents $1 \mathrm{~mm}$. 
Plate VI
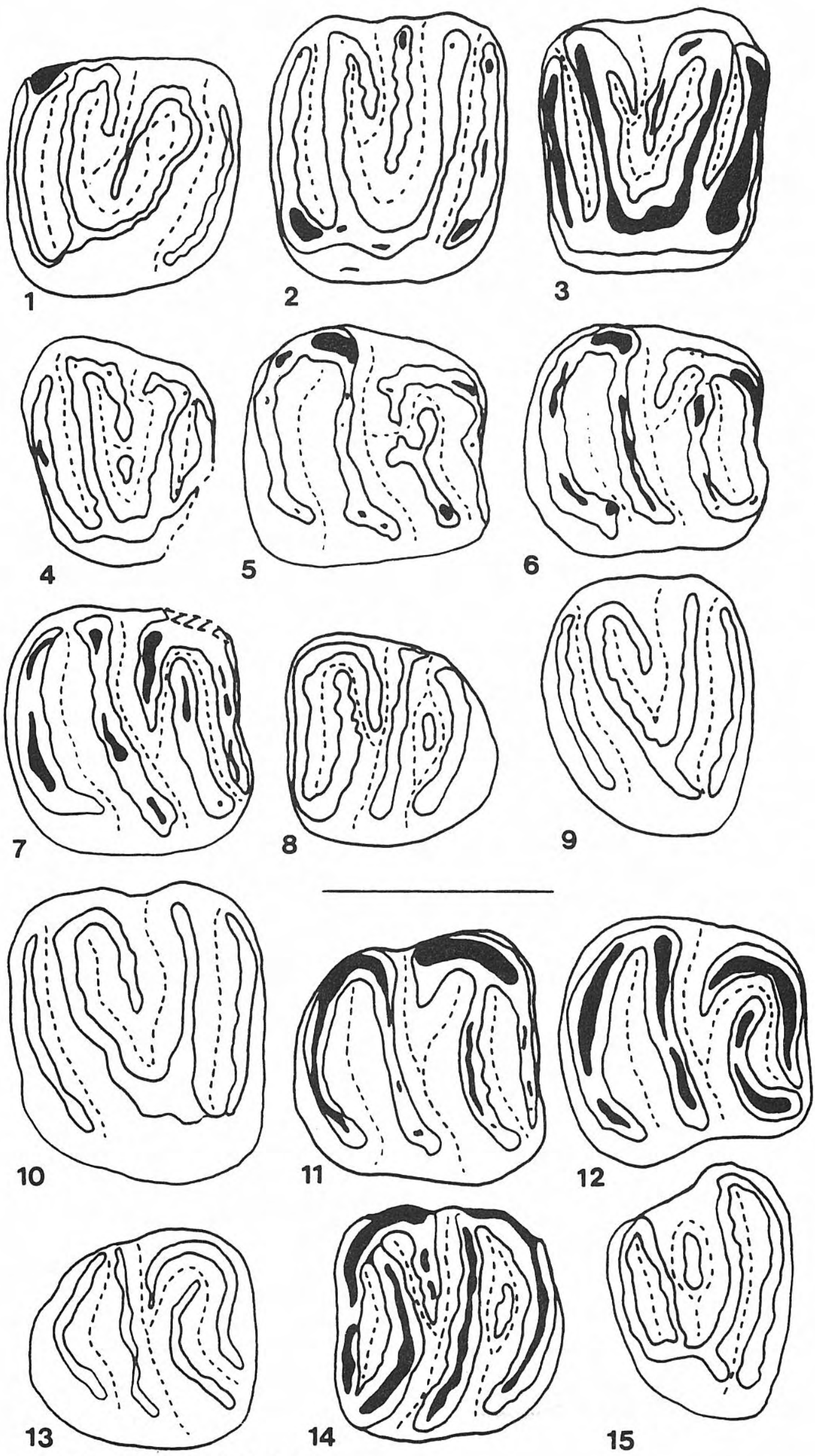
A well-developed anterior centroloph is present. This specimen falls within the morphological and metrical range of variation of $P$. murinus from the Lower Miocene of Spain.

\section{Armantomys cf. bijmai (Lacomba \& Martínez- Salanova, 1988) \\ Plate VI, figs. 10-13}

Material and measurements: $1 \mathrm{M}^{1}(10.4 \times 12.2), 1$ fragmentary $\mathrm{M}_{1}, 1 \mathrm{M}_{2}(10.5 \times 10.2), 1 \mathrm{M}_{3}(9.5 \times 9.1)$.

\section{Description}

$\mathrm{M}^{1}$ : Relatively hypsodont. The protoloph meets the metaloph at the high protocone. The posteroloph is connected halfway to the posterior wall of the protocone. Labially a furrow separates this ridge from the paracone. A well-developed anterior centroloph is present.

$M_{1,2}$ : Both specimens are worn. The anterolophid is separated from the protoconid. The centrolophid is short. Postero- and mesolophid meet at the entoconid.

$\mathrm{M}_{3}$ : The ridges are high. The anterolophid is separated from the protoconid. The centrolophid is very short. The metalophid does not join the metaconid. The meso- and posterolophid meet at the entoconid. The posterolophid meets the mesolophid labially at the posterior wall of the mesoconid.

\section{Discussion}

Morphologically the few teeth from Parrales agree with those of $A$. bijmai from the Lower Miocene of Santa Cilia (MN1) and Quel 1 (MN2a), Daams (1990), but the size of our material is slightly smaller.

\section{Gliridae indet.}

Pl. VI, figs. 14,15

Material and measurements: $1 \mathrm{M}^{3}(7.8 \times 10.7), 1 \mathrm{M}_{2}(9.5 \times$ - -).

\section{Description}

$\mathrm{M}^{3}$ : A continuous endoloph is present. The anteroloph joins the paracone. Proto-and metaloph meet the endoloph separately. An isolated posterior centroloph of medium length is present. The posteroloph joins the metacone.

$\mathrm{M}_{2}$ : The anterolophid is separated from the protoconid. The metalophid meets the base of the metaconid. The centrolophid is of medium length. Meso-and posterolophid meet at the entoconid. An extra ridge is present in the posterior valley.

\section{BIOSTRATIGRAPHY}

The faunal lists of Canales and Parrales are as follows:

$\begin{array}{lrr}\text { CANALES } & \text { N M1-2 } & \\ \text { Issiodoromys limognensis } & 16 & 21.1 \% \\ \text { Plesiosminthus sp. } & 5 & 6.5 \% \\ \text { Eomys cf. zitteli } & 29 & 38.2 \% \\ \text { Heteroxerus sp. } & 1 & 1.3 \% \\ \text { Peridyromys sp. } & 11 & 14.5 \% \\ \text { Adelomyarion sp. } & 3 & 3.9 \% \\ \text { Adelomyarion cornelii } & 3 & 3.9 \% \\ \text { Pseudocricetodon } \text { cf. adroveri } & 8 & 10.5 \% \\ \text { Total Number of M1-2 } & 76 & \end{array}$

\section{PARRALES}

N M1-2

Issiodoromys pseudanaema

Plesiosminthus schaubi

Eomys huerzeleri

Rhodanomys hugueneyae

Peridyromys murinus

Armantomys cf. bijmai

Eucricetodon cf. collatus

Adelomyarion vireti

Total Number of M1-2

7
67
17
8
3
2
4
1
109

$6.4 \%$

$61.5 \%$

$15.6 \%$

$7.3 \%$

$2.8 \%$

$1.8 \%$

$3.7 \%$

$0.9 \%$

The most useful species for correlation of the Canales fauna is Issiodoromys limognensis which is exclusive for MP28 with Pech du Fraysse as reference locality. Another Spanish fauna from MP28 is that of Vivel del Río from the Teruel Basin (Hugueney et al., 1987) which contains nineteen rodent species (Fig. 4). Characteristic species shared by Canales and Vivel del Río are Issiodoromys limognensis, Eomys zitteli, Adelomyarion cornelii, Adelomyarion sp., and Pseudocricetodon adroveri. Canales is much poorer and has only nine rodent species. Part of this poverty is due to the small size of our sample but Eucricetodon dubius, Eomys major and Microdyromys praemurinus, which are frequent in Vivel, are clearly missing in Canales. Another difference between the two faunas is the presence in Canales of the very small-sized Plesiosminthus sp. contrasting with the larger sized Plesiosminthus promyarion from Vivel (see Fig. 4 in Álvarez Sierra et al., 1996). Some features may point at a younger age for the Canales fauna such as the absence of Eucricetodon dubius. In Late Oligocene faunas of MP27-28 from western Europe this species is very common and it is substituted by Eucricetodon praecursor at the turn of MP28/29. But the faunal difference may also be due to the different paleoenvironmental setting of the localities; the Vivel fauna is found in a lacustrine sequence, whereas the Canales level forms part of an extensive fluvial system (Daams et al., 1996), the so-called Tórtola fan (Díaz Molina \& Tortosa, 1996). Other Spanish rodent faunas attributed to MP28 are the ones from Mirambueno 1 and 2A from the same area as Vivel del Río (Freudenthal, 1994; Freudenthal et al., 1994). Unfortunately only the Cricetidae have been studied (op cit.) and consequently complete faunal lists are not available. But the presence of Adelomyarion cornelii and Eucricetodon dubius in Mirambueno 1 and $2 \mathrm{~A}$ and that of Pseudocricetodon adroveri in Mirambueno 2A confirms this correlation.

Agustí et al. (1985) and (1987) described a succession 


\begin{tabular}{|c|c|c|c|}
\hline 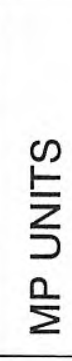 & $\begin{array}{l}\text { 出 } \\
\stackrel{E}{E} \\
\frac{1}{0} \\
0 \\
0\end{array}$ & 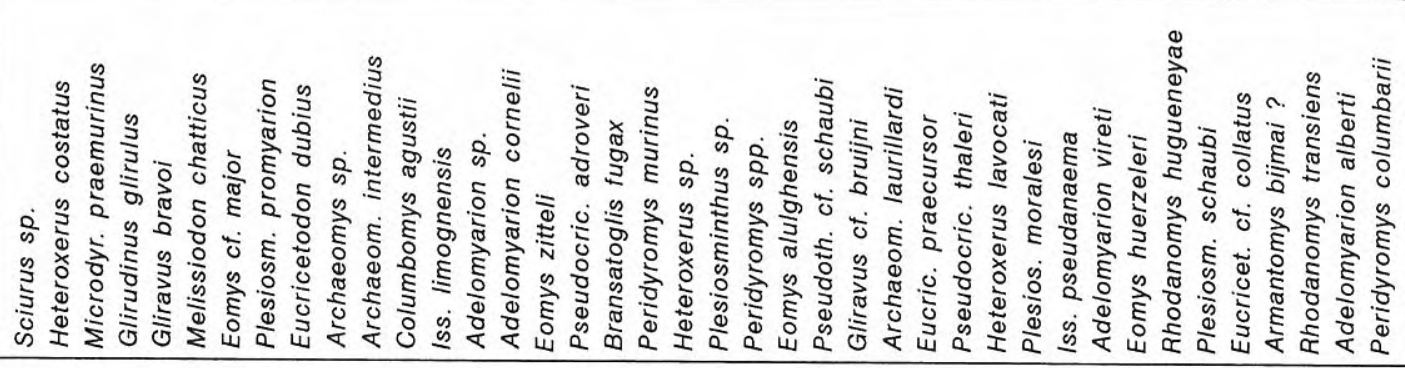 & 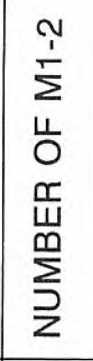 \\
\hline 30 & $\begin{array}{c}\text { SAY } \\
6\end{array}$ & & 140 \\
\hline \multirow{3}{*}{29} & PAR & 00000 & 109 \\
\hline & $\begin{array}{c}\text { SAY } \\
1\end{array}$ & 0000 & 85 \\
\hline & HIN & 000000000 & 229 \\
\hline \multirow{2}{*}{28} & CAN & 0000 & 76 \\
\hline & VIV & 00000000000000000 & 2696 \\
\hline
\end{tabular}

Figure 4. Distribution chart of late Oligocene rodents from Central Spain. VIV = Vivel del Río; CAN = Canales; HIN = Hinojosa de Jarque 2; SAY-1 = Sayatón 1; PAR = Parrales; SAY-6 = Sayatón 6.

of Late Oligocene/Early Miocene micromammal faunas from the eastern Ebro Basin. Faunas such as Fraga 4 and Les Canotes were correlated to MP27 because of the presence of Issiodoromys quercyi, the next ones in age such as Fraga 7 and 11 were assigned to MP30 mainly because of the presence of Rhodanomys transiens, and the more modern ones such as Torrente de Cinca 68 and Ballobar 21 to MN1 because these faunas contain Rhodanomys schlosseri. Hence, MP28 and MP29 would not be represented. In a later stratigraphic study combined with magnetostratigraphy (Agustí et al., 1994) a different correlation was proposed and the MP27 faunas (Schmidt-Kittler, 1987) were assigned to MP28/29. However, the referred faunas are void of any taxa characteristic of MP28/29, but several of these do have Issiodoromys quercyi_which is exclusive for MP27. Since the biochronological subdivision of the Late Oligocene is mainly based on the evolution of Theridomyidae, we think that the correlation such as proposed by Agustí et al. (1987) is the correct one. As our two faunas are from MP28 and 29 respectively, we will not compare our data to the Ebro succession.

The fauna of Parrales is correlated to MP29 because of the presence of Issiodoromys pseudanaema and Eomys huerzeleri (Fig. 5). It shares with Sayatón 1 from the Madrid Basin (Álvarez Sierra et al., 1996) Adelomyarion vireti, Eomys huerzeleri and Rh. hugueneyae (Fig. 4). However, Parrales is considered to represent a more modern fauna than Sayatón 1 since $R h$. hugueneyae is more evolved, and since it contains Plesiosminthus schaubi which is considered to be the descendant of $P$. moralesi from Sayatón 1. Our Parrales fauna is somewhat younger than that of Hinojosa de Jarque 2 from a small intramontane Basin in Teruel (Cuenca \& Canudo, 1994) because it has E. cf. collatus and Plesiosminthus schaubi whereas in Hinojosa the respectively earlier representatives $E$. praecursor and $P$. moralesi are present (Fig. 4).

After comparing the Parrales fauna to other European ones, it appeared that there are two faunal groups in MP29 (Fig. 5); one older one without Rhodanomys and one younger one with Rhodanomys hugueneyae. Both groups contain Eomys huerzeleri. Eomys is absent beyond MP29. This successional bipartition on the basis of Eomyidae is recognizable in western and central Europe. In the Freshwater Molasse of Switzerland and Savoy, Engesser (1990) recognized faunas with Eomys huerzeleri and without Rhodanomys which he correlated to the Rickenbach Zone. Other, more modern faunas such as La Cornalle, Rances, Brochene Fluh 4/5, Basel-St. Jakob with E. huerzeleri and Rhodanomys were assigned to either Rickenbach (+) or to Küttigen (-) such as Brochene Fluh 19/20. The Hinojosa fauna from Spain contains Eomys huerzeleri but it lacks Rhodanomys and may consequently be correlated to the older faunal group of MP29. Sayatón 1 and Parrales have both E. huerzeleri and Rhodanomys and belong to the more modern faunal group. Our Parrales fauna also contains Eucricetodon cf. collatus which confirms its correlation to the more modern faunal group. 


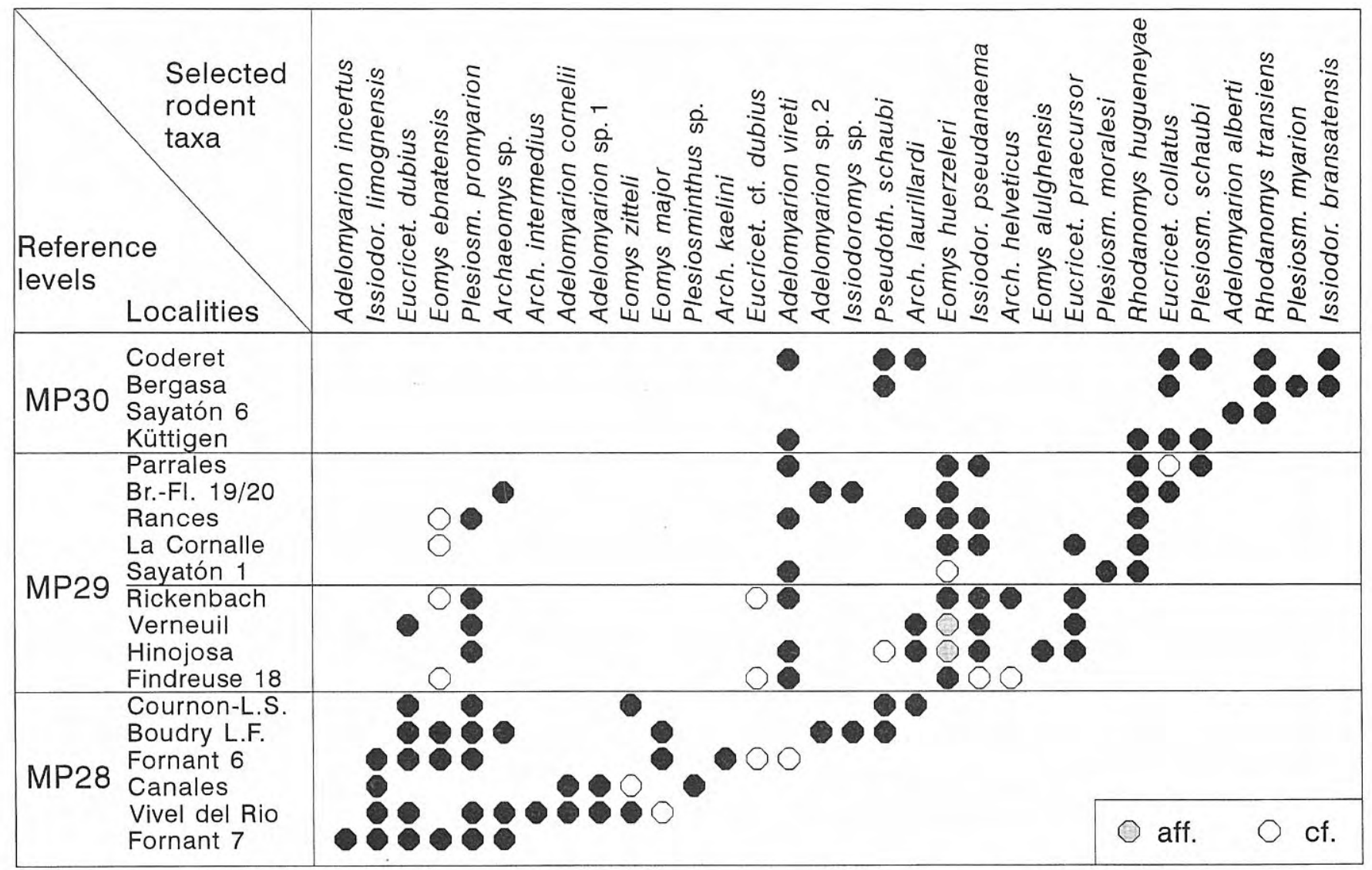

Figure 5. Distribution chart of selected rodent taxa from fluvio-lacustrine faunas from the Upper Oligocene of Western and Central Europe. Data are from the following sources: For the Swiss localities Fornant 7 and 6, Boudry L. F., Findreuse 18, Rickenbach, La Cornalle, Rances, Brochene-Fluh 19/20, Küttigen (Burbank et al., 1992; Engesser, 1987, 1990; Engesser \& Mayo, 1987; Engesser et al., 1984; Mojon et al., 1985; Hugueney et Kissling, 1972). For the Spanish locality Bergasa (Álvarez Sierra et al., 1987); and for the French fauna Cournon-les-Souméroux (Brunet et al., 1981). The other localities are referred to in the text.

Aguilar et al. (1997) correlated the faunas of Canales and Parrales erroneously to MP 29 and MP30 respectively, following an earlier correlation of Álvarez Sierra et al. (1994). The reasons of these errors are not clear.

\section{ACKNOWLEDGEMENTS}

The authors want to thank the following persons for help in the field: M. Díaz Molina (Madrid), N. López Martínez (Madrid), M. Freudenthal (Leiden, Holland), J. Moltzer (Haarlem, Holland), A.J van der Meulen (Utrecht, Holland), J.I. Lacomba Andueza (Valencia), and Mrs. J. van der Meulen (Nieuwegein, Holland). M.A.A.S. is grateful to Dr. M. Vianey-Liaud (Montpellier) for her hospitality during her stay in Montpellier in 1993. M. Hugueney (Lyon) and N. López Martínez critically read the manuscript. We gratefully acknowledge financial support by the D.G.I.C.Y.T. (projects PB85-0022, PB92-0013 and PB95-0114).

\section{REFERENCES}

Aguilar, J.-P., Legendre, S. et Michaux, J. (Eds) 1997. Synthèses et tableaux de corrélations. Actes du Congrès
BiochroM '97. École Pratique des hautes Études. Sciences de la Vie et de la Terre, 21, 767-805.

Agustí, J., Anadón, P., Arbiol, S., y Cabrera, L. 1985. Biozonación mediante roedores (Mammalia) del tránsito Oligoceno-Mioceno en el sector sureste de la cuenca del Ebro. Paleontologia i Evolució, 18, 131-149.

Agustí, J., Anadón, P., Arbiol, S., Cabrera L., Colombo, F. \& Sáez, A. 1987. Biostratigraphical characteristics of the Oligocene sequences of North-Eastern Spain (Ebro and Campins Basins). Münchner Geowissenschaftliche Abhandlungen, (A), 10, 35-42.

Agustí, J., Barberá, X., Cabrera, L., Parés, J.M. \& Llenas, M. 1994. Magnetostratigraphy of the Oligocene-Miocene transition in the Ebro Basin (Eastern Spain), State of the Art. Münchner Geowissenschaftliche Abhandlungen, (A), 26, 161-172.

Álvarez Sierra, M.A. 1987. Estudio sistemático y bioestratigráfico de los Eomyidae (Rodentia, Mammalia) del Oligoceno superior y Mioceno inferior español. Scripta Geologica, 86, 1-207.

Álvarez Sierra, M. A., Daams, R., Lacomba, J. I., López Martínez, N. \& Sacristán, M.A. 1987. Succession of micromammal faunas in the Oligocene of Spain. Münchner Geowissenschaftliche. Abhandlungen, (A), 10, 43-48. 
Álvarez Sierra, M. A., Daams, R. \& Peláez-Campomanes, P. 1994. Synthesis of Late Oligocene/Early Miocene micromammal faunas of the Loranca Basin (Province of Cuenca, Spain). Comunicaciones de las $X$ Jornadas de Paleontología, 18-21.

Álvarez Sierra, M. A., Daams, R. \& Lacomba Andueza, J.I. 1996. The rodents from the Upper Oligocene of Sayatón 1, Madrid Basin (Guadalajara, Spain). Proceedings of the Koninklijke Nederlandse Akademie van Wetenschappen, 99 (1-2), 1-23.

Bahlo, E. 1975. Die Nagetierfauna von Heimersheim bei Alzey (Rheinhessen, Westdeutschland) aus dem Grenzbereich Mittel-/Oberoligozän und ihre stratigraphische Stellung. Abhandlungen hessisches Landesamt für Bodenforschung, 71, 1-182.

Baudelot, S. et Olivier, P. 1978. Les rongeurs (Mammalia, Rodentia) de l'Oligocène Terminal de Dieupentale (SudOuest de la France, Tarn-et-Garonne). Géobios, 11, 5-19.

Brunet, M. 1979. Les Cricetidae (Rodentia, Mammalia) de La Milloque (Bassin d'Aquitaine), horizon-repère de l'Oligocène supérieur. Géobios, 1, 653-673.

Brunet, M., Hugueney, M. et Jehenne, Y. 1981. Cournonles-Soumeroux: un nouveau site à Vertébrés d'Auvergne; sa place parmi les faunes de l'Oligocène supérieur d'Europe. Géobios, 14, 323-359.

Burbank, D.W., Engesser, B., Matter, A. \& Weidmann, M. 1992. Magnetostratigraphic chronology, mammalian faunas, and stratigraphic evolution of the Lower Freshwater Molasse, Haute-Savoie, France. Eclogae geologicae Helvetiae, 85, 399-431.

Comte, B. 1985. Eléments nouveaux sur l'évolution des genres Eucricetodon et Pseudocricetodon (Eucricetodontinae, Rodentia, Mammalia) de l'Oligocène d'Europe occidentale. Palaeovertebrata, 15, 1-69.

Comte, B. et Vianey-Liaud, M. 1987. Nouveaux Eomyidae du Paléogène d'Europe occidentale. Comptes Rendus de l'Académie des Sciences, Paris, 304, II, 15, 951-955.

Cuenca, G. et Canudo, J.I. 1994. Les Micromammifères de l'Oligocène Supérieur des calcaires de Hinojosa de Jarque (Montalbán-Aliaga, Teruel, Espagne). Géobios, 27, 353-384.

Daams, R. 1981. The dental pattern of the dormice Dryomys, Myomimus, Microdyromys and Peridyromys. Utrecht Micropaleontological Bulletin, Special Publication, 3, 1105.

Daams, R. 1989. The micromammal fauna from the Upper Oligocene of Sayatón 6, Madrid Basin, prov. of Guadalajara, Spain. Scripta Geologica, 89, 57-69.

Daams, R. 1990. Hypsodont Myomiminae (Gliridae, Rodentia) from the Miocene and the Oligocene-Miocene boundary interval of Spain. Scripta Geologica, 95, 1-63.

Daams, R., Freudenthal, M., Lacomba, J.I. \& Álvarez Sierra, M.A. 1989. Upper Oligocene micromammals from Pareja, Loranca Basin, prov. of Guadalajara, Spain. Scripta Geologica, 89, 27-56.

Daams, R., Álvarez Sierra, M.A., Van Der Meulen, A.J. \& Peláez-Campomanes, P. 1996. Paleoecology and paleoclimatology of micromammal faunas from Upper Oligocene-Lower Miocene sediments in the Loranca Basin, Province of Cuenca, Spain. In: Spanish Tertiary
Basins, the stratigraphic record of crustal kinematics (Eds. C. Dabrio \& P. Friend). Cambridge University Press, 295-299.

Díaz Molina, M. y López Martínez, N. 1979. El Terciario continental de la Depresión Intermedia (Cuenca). Biostratigrafía y Paleogeografía. Estudios geológicos, 35, 149-167.

Díaz Molina, M. \& Tortosa, A. 1996. Fluvial fans of the Loranca Basin, Late Oligocene-Early Miocene, central Spain. In: Spanish Tertiary Basins, the stratigraphic record of crustal kinematics (Eds. C. Dabrio \& P. Friend). Cambridge University Press, 300-307.

Dienemann, A. 1987. Die Gattungen Eucricetodon und Pseudocricetodon (Rodentia, Mammalia) aus dem Oligozän Süddeutschlands. Abhandlungen Bayerische Akademie der Wissenschaften, Mathematischnaturwissenschaftliche Klasse, Neue Folge, 165, 1-158.

Engesser, B. 1982. Le plus grand représentant du genre Eomys (Rodentia, Mammalia) de l'Oligocène de l'Europe: Eomys huerzeleri nov. sp. Géobios 15, 261-266.

Engesser, B. 1985. Die Gattung Eucricetodon (Mammalia, Rodentia) im Grenzbereich Oligozän/Miozän. Eclogae geologicae Helvetia, 78, 669-692.

Engesser, B. 1987. New Eomyidae, Dipodidae, and Cricetidae (Rodentia, Mammalia) of the Lower Freshwater Molasse of Switzerland and Savoy. Eclogae geologicae Helvetiae, 80, 943-994.

Engesser, B. 1990. Die Eomyidae (Rodentia, Mammalia) der Molasse der Schweiz und Savoyens. Systematik und Biostratigraphie. Schweizerische Paläontologische Abhandlungen, 112, 1-144.

Engesser, B. \& Mayo, N.A. 1987. A biozonation of the Lower Freshwater Molasse (Oligocene and Agenian) of Switzerland and Savoy on the basis of fossil mammals. Münchner Geowissenschaftliche. Abhandlungen, (A), 10, 67-84.

Engesser, B., Mayo, N.A. et Weidmann, M. 1984. Nouveaux gisements de mammifères dans la Molasse subalpine vaudoise et fribourgeoise. Mémoires Suisses de Paléontologie, 107, 1-39.

Freudenthal, M. 1994. Cricetidae (Rodentia, Mammalia) from the Upper Oligocene of Mirambueno and Vivel del Río (prov. Teruel, Spain). Scripta Geologica, 104, 1-55.

Freudenthal, M., Hugueney, M. \& Moissenet, E. 1994. The genus Pseudocricetodon (Cricetidae, Mammalia) in the Upper Oligocene of the province of Teruel (Spain). Scripta Geologica, 104, 57-114.

Hugueney, M. 1968. Les Gliridés (Rodentia) de l'Oligocène supérieur de St-Victor-la-Coste (Gard). Palaeovertebrata, 2, 1-16.

Hugueney, M. 1969. Les rongeurs (Mammalia) de l'Oligocène supérieur de Coderet-Bransat (Allier). Documents du Laboratoire de géologie Facultes des Sciences, Lyon, 34, 1-227.

Hugueney, M. 1984. Verneuil (Allier), gisement de petits mammifères de l'Oligocène Supérieur. Revue Scientifique du Bourbonnais, 128-140.

Hugueney, M. et Kissling, D. 1972. Nouveaux gisements de mammifères de l'Oligocène supérieur de Suisse occidentale. Géobios, 5, 55-66. 
Hugueney, M. et Vianey-Liaud, M. 1980. Les Dipodidae (Mammalia, Rodentia) d'Europe occidentale au Paléogène et au Néogène inférieur: origine et evolution. Palaeovertebrata, Mémoire Jubilaire René Lavocat, 303-342.

Hugueney, M., Adrover, R., Moissenet, E. et SchmidtKittler, N. 1987. Les Mammifères de Vivel del Río (prov. de Teruel, Espagne; Oligocène supérieur), un riche gisement stratifié en comparaison avec des faunes karstiques. Münchner Geowissenschaftliche Abhandlungen, (A), 10, 117-130.

Kristkoiz, A. 1992. Zahnmorphologische und schädelanatomische Untersuchungen an Nagetieren aus dem Oberoligozän von Gaimersheim (Süddeutschland). Abhandlungen Bayerische Akademie der Wissenschaften, Mathematisch-naturwissenschaftliche Klasse, Neue Folge, 167, 137 pp.

Lacomba, J.I. y Morales, J. 1987. Los mamíferos del Oligoceno superior de Carrascosa del Campo (Prov. Cuenca, España). Münchner Geowissenschaftliche Abhandlungen, (A), 10, 289-299.

Mojon, P.O., Engesser, B., Berger, J.P., Bucher, H. et Weidmann , M. 1985. Sur l'âge de la Molasse d'Eau douce inférieure de Boudry NE. Eclogae geologicae Helvetiae, 78, 631-667.

Schmidt-Kittler, N. (Ed.) 1987. International Symposium on Mammalian Biostratigraphy and Paleoecology of the European Paleogene - Mainz, February $18^{\text {th }}-21^{\text {st }} 1987$. Münchner Geowissenschaftliche Abhandlungen, (A), 10, $312 \mathrm{pp}$.

Schmidt-Kittler, N. \& Vianey-Liaud, M. 1987. Morphometric analysis and evolution of the dental pattern of the genus Issiodoromys (Theridomyidae, Rodentia) of the European Oligocene as a key to its evolution. Proceedings of the Koninklijke Nederlandse Akademie van Wetenschappen, Proc. B, 90, 281-306.

Vianey-Liaud, M. 1972. L'évolution du genre Theridomys à l'Oligocène moyen. Interêt biostratigraphique. Bulletin du Muséum national d'Histoire Naturelle, Paris, 3, 98, Sc. Terre, 18, 295-372.

Werner, J. 1994. Beitrage zur Biostratigraphie der Unteren Süsswasser-Molasse Süddeutschlands - Rodentia und Lagomorpha (Mammalia) aus den Fundstellen der Ulmer Gegend. Stuttgarter Beitrage zur Naturkunde, Serie B (Geologie und Paläontologie), 200, 1-263.

Manuscrito recibido: 10 de febrero, 1998 Manuscrito aceptado: 15 de junio, 1998 